\title{
Supracrustal rocks in the Kuovila area, Southern Finland: structural evolution, geochemical characteristics and the age of volcanism
}

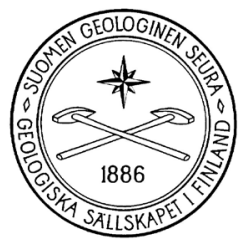

\author{
Pietari SkytTä*, Asko Käpyaho \& Irmeli MäNTtäRI \\ Geological Survey of Finland, P.O. Box 96, FI-02151 Espoo, Finland
}

\section{Abstract}

The supracrustal rocks of the Kuovila area in the Palaeoproterozoic Svecofennian Uusimaa Belt, southern Finland, consist mainly of volcaniclastic rocks associated with banded iron formations (BIFs) and marbles. Small ZnS and PbS mineralizations are occasionally located within the marbles. Some primary features are well preserved in the sedimentary and volcanic rocks, including lamination in tuffites and banded iron formations.

Geochemical results show that the volcanism was bimodal and it mainly had volcanic arc affinity. Specific geochemical indicators suggesting a volcanic arc origin for the Kuovila volcanic rocks include: I) Enrichment of LILE over the HFSE elements and 2) Distinctly low $\mathrm{Nb}$ and Ta contents in relation to Th, Ce and LREE. Geochemistry of the Kuovila area volcanic rocks is very similar to those of the Orijärvi and Kisko formations, located $\sim$ I $\mathrm{km}$ NE of Kuovila.

Felsic tuff in the Kuovila area was dated at I $89 \mid \pm 4$ Ma by the U-Pb system on zircons. Consequently volcanism was contemporaneous with magmatism in the adjacent Orijärvi area, thus representing the earliest identified volcanic stage in the southern Svecofennian Uusimaa Belt.

Early deformation structures within the Kuovila area are suggested to relate to low-

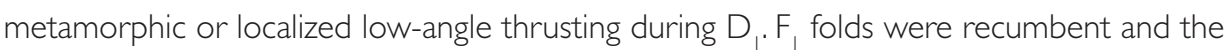
$\mathrm{S}$, cleavages are generally weak. Thrusting was followed by approximately $\mathrm{N}-\mathrm{S}$ contraction with upright, peak-metamorphic $F_{2}$ folding overprinting $D_{1}$ structures and defining the Kuovila synform. Two separate intrusive phases include a synvolcanic granodiorite-dioritegabbro association and a weakly $\mathrm{S}_{2}$-foliated syn- $\mathrm{D}_{2}$ granodiorite. Anatectic granites and associated migmatizing veins are absent, therefore suggesting that $D_{2}$ pre-dates the $\sim 1.84$ I.82 Ga metamorphic event in the Southern Svecofennian Arc Complex (SSAC). D 2 structures in the Kuovila area are suggested to correlate with the early structures with associated axial planar cleavages in the Orijärvi area. $D_{2}$ strain is localized into axial planar high strain zones and the curvilinear patterns of the $B_{2}$ fold axes probably result from vertical stretching during $D_{2}$.

Keywords: supracrustals, metavolcanic rocks, igneous rocks, geochemistry, deformation, structural geology, volcanism, Palaeoproterozoic, Kuovila, Finland

* Corresponding author email: pietari.skytta@gtk.fi 


\section{Introduction}

The Kuovila area is located in the Palaeoproterozoic Svecofennian - 1.90-1.80 Ga supracrustal Uusimaa Belt, southern Finland (Fig. 1), $12 \mathrm{~km} \mathrm{SW}$ of the Orijärvi area, known for its $\mathrm{Cu}-\mathrm{Zn}$ - $\mathrm{Pb}$-mineralizations (e.g. Mäkelä, 1989) and as the area in which Eskola (1915) first developed the metamorphic facies concept. The Uusimaa Belt consists of bimodal volcanic rocks, metapelites and metagraywackes (Simonen, 1953; Koistinen, 1992), massive sulphide deposits (Latvalahti, 1979), marbles (Reinikainen, 2001) and banded iron formations (Keinänen, 1980; Sipilä, 1981). Similar lithologies and ore deposits are typical of the Bergslagen area in south-central Sweden (Lundström \& Papunen, 1986; Allen et al., 1996) and for that reason these two supracrustal belts are often correlated (Ekdahl, 1993; Nironen, 1997).

The age of volcanism in the Uusimaa Belt has recently been constrained rather well; conventional U$\mathrm{Pb}$ age on zircons from felsic volcanic rocks at Norrlammala, $35 \mathrm{~km}$ WSW of Kuovila, is $1888 \pm 11 \mathrm{Ma}$ (Reinikainen, 2001). Väisänen \& Mänttäri (2002) showed that the age of volcanism is $1895 \pm 3 \mathrm{Ma}$ in the Orijärvi formation, lowermost in the Orijärvi area stratigraphy, and $1878 \pm 4 \mathrm{Ma}$ in the Kisko formation, overlying the Orijärvi formation. Ages for intrusive rocks from the Uusimaa Belt include a quartz diorite at $1891 \pm 13 \mathrm{Ma}$ (Huhma, 1986) and granodiorites at Orijärvi at $1898 \pm 4 \mathrm{Ma}$ (Väisänen et al.,
$2002)$ and at $1891 \pm 13 \mathrm{Ma}$ (Huhma, 1986), and have been considered synvolcanic (e.g. Colley \& Westra, 1987; Väisänen \& Mänttäri, 2002). A discordantly cutting gabbroidic pegmatite in the southern part of the SSAC is dated at $1885 \pm 7 \mathrm{Ma}$, setting a minimum age for the volcano-sedimentary rocks and a maximum age for the first deformation phase with associated penetrative metamorphic fabric (Hopgood et al., 1983). The lateorogenic granitoids of the southern Svecofennian domain are generally anatectic Stype microcline granites (Nironen, 2003) and mostly indicate ages between 1.82 and $1.84 \mathrm{Ga}$ (Huhma, 1986; Suominen, 1991; Kurhila et al., 2004), thus being concurrent with the peak of the younger metamorphic event (Mouri et al., 2005). In addition, a younger, A-type resembling granite crosscutting the surrounding migmatites at Karjaa yielded an age of $1826 \pm 11 \mathrm{Ma}$ (Jurvanen et al., 2005).

Analysis of strain and kinematic history in a polydeformed, highly migmatized region, such as the Svecofennian domain of southern Finland, is particularly difficult due to destruction of early structures at highgrade metamorphic events, associated migmatization and multiple intrusive events. Resolution of the original tectonic environment of these rocks, their geometry and kinematic history, and the relationship between deformation, magmatic events and metamorphism provide important constraints on understanding the Svecofennian orogeny. As a non-migmatized area with preserved deformation structures related to

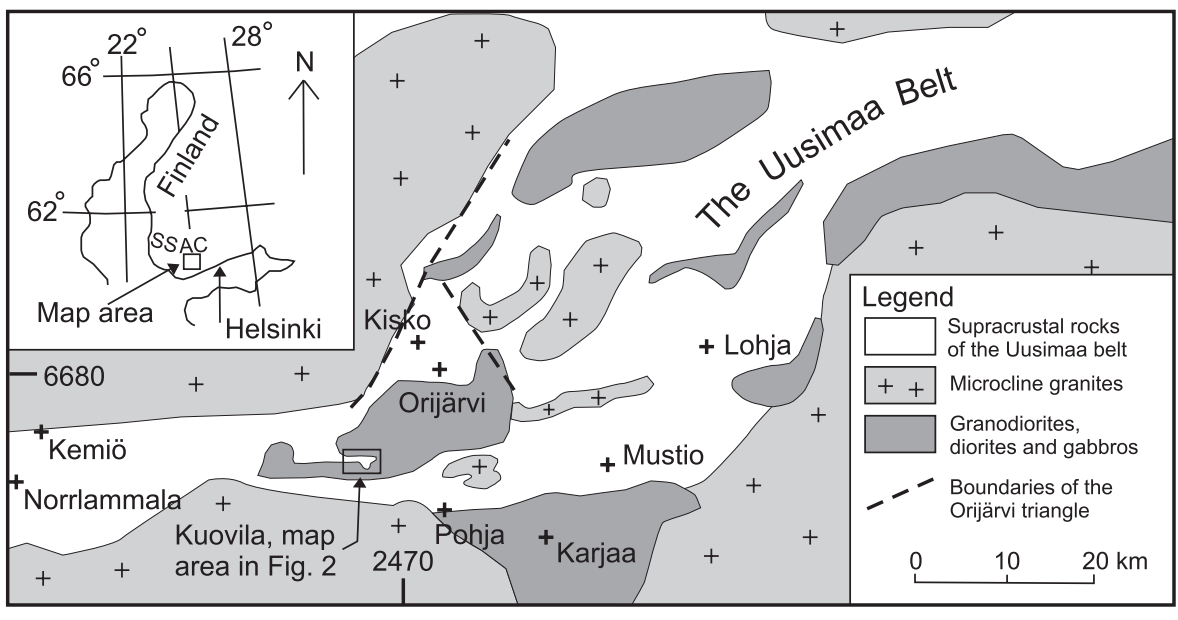

Fig. I. Geological setting of the Kuovila area. Simplified after Schreurs \&Westra (1986). SSAC = Southern Svecofennian Arc Complex of Väisänen et al. (2002). 
the earliest stages of the tectono-metamorphic history of the SSAC, the Kuovila area provides an opportunity for this. In particular, some constraints on spatial strain variations and kinematic constraints of the main deformational events may be suggested. Also the primary geochemical affinities of the volcanic rocks in the Kuovila area were studied, and combined with the tectonic evolution and the new $\mathrm{U}-\mathrm{Pb}$ age determination they provide information on the probable tectonic setting of the volcanism during the Svecofennian orogenesis.

\section{Geological setting}

Eskola et al. (1919) compiled the first geological map for the Kuovila area, after having previously described igneous and pyroclastic rocks (Eskola, 1914). Later on, Tavela (1950) produced a geological map of Kuovila area with stratigraphical and structural interpretations. Tuominen (1957) published a geological map of the Orijärvi area with a further structural interpretation. Käpyaho (2001) studied the area with particular emphasis on the preserved primary structures and geochemical characteristics.

The Svecofennian domain collided against the Archean continent at 1.910-1.885 Ga (Korsman et al., 1999), whereafter the Uusimaa Belt rocks were deformed and metamorphosed episodically (Nironen, 1997) or semicontinuosly (Gorbatshev \& Bogdanova, 1993) during the Svecofennian orogeny, at ca. 1.89 to $1.80 \mathrm{Ga}$. Two metamorphic events with associated migmatization took place between 1.8851.810 Ga in the Southern Svecofennian Arc Complex (SSAC, cf. Väisänen et al., 2002). The older event is bracketed between $\mathrm{U}-\mathrm{Pb}$ ages at $1882 \pm 6 \mathrm{Ma}$ and $1877 \pm 6 \mathrm{Ma}$ on sphenes and monazites, respectively (Hopgood et al., 1983). The younger event is characterized by high-temperature, low-pressure (HTLP) conditions (Korsman et al, 1999), P estimates ranging from 3 to $5 \mathrm{kbar}$ and $\mathrm{T}$ from $550^{\circ} \mathrm{C}$ to $825^{\circ} \mathrm{C}$ (Schreurs \& Westra, 1986), thus locally reaching granulite facies conditions. Peak metamorphic conditions of the younger event prevailed at $-1.830-1.815 \mathrm{Ga}$ (Levin et al., 2005; Mouri et al., 2005).

The tectonic setting and the depositional envi- ronment of the Uusimaa Belt rocks have been discussed in several papers; the belt being interpreted as a palaeo-island arc (e.g. Hietanen, 1975; Latvalahti, 1979; Mäkelä, 1989; Gáal, 1990; Ploegsma \& Westra, 1990) or a back-arc basin (e.g. Colley \& Westra, 1987; Nironen, 1997). Väisänen \& Mänttäri (2002) described the Orijärvi area as resembling a modern volcanic arc with back-arc basin, and identified the progressive development of geochemical characteristics in the volcanic rocks, starting with bimodal magmatism and evolving to intermediate compositions after 10-15 Ma.

Previous structural studies have identified two (Ehlers et al., 1993), three (Shreurs \& Westra, 1986; Bleeker \& Westra, 1987; Ploegsma \& Westra, 1990) or four deformation phases (Verhoef \& Dietvorst, 1980; van Staal \& Williams, 1983; Kilpeläinen \& Rastas, 1990; Levin et al., 2005) in the SSAC. The early deformation phases are suggested to be thrust-related recumbent folds, while the interpreted tectonic transport directions are variable (Ehlers et al., 1993; van Staal \& Williams, 1983). Ehlers et al. (1993) defined two recumbent fold sets: the first set $\left(\mathrm{D}_{1}\right)$ deformed the 1.89$1.88 \mathrm{Ga}$ granitoids and the second $\left(\mathrm{D}_{2}\right)$ set deformed also the 1.84-1.83 Ga microcline granites, thereafter transitioning into upright folding. Generation of the 1.84-1.81 Ga microcline granites is suggested to predate the end of recumbent $F_{1}$ folding (Shreurs \& Westra, 1986) and the early stage of the recumbent, thrustrelated $\mathrm{D}_{2}$ of Ehlers et al. (1993). Thus, it also predates the peak metamorphic main folding, characterized by E-W trending upright folds (Schreurs \& Westra, 1986; Bleeker \& Westra, 1987; Ploegsma \& Westra, 1990; Levin et al., 2005). In addition, Ploegsma \& Westra (1990) recognized the Orijärvi triangle as a non-migmatized low tectonic strain area with preserved early deformation structures.

\section{Description of the rock units}

\section{I. Supracrustal rocks}

In the Kuovila area, metamorphosed, non-migmatitic volcaniclastic deposits, principally tuffs and tuffites dominate the supracrustal rocks (Fig. 2). Tuffs are 


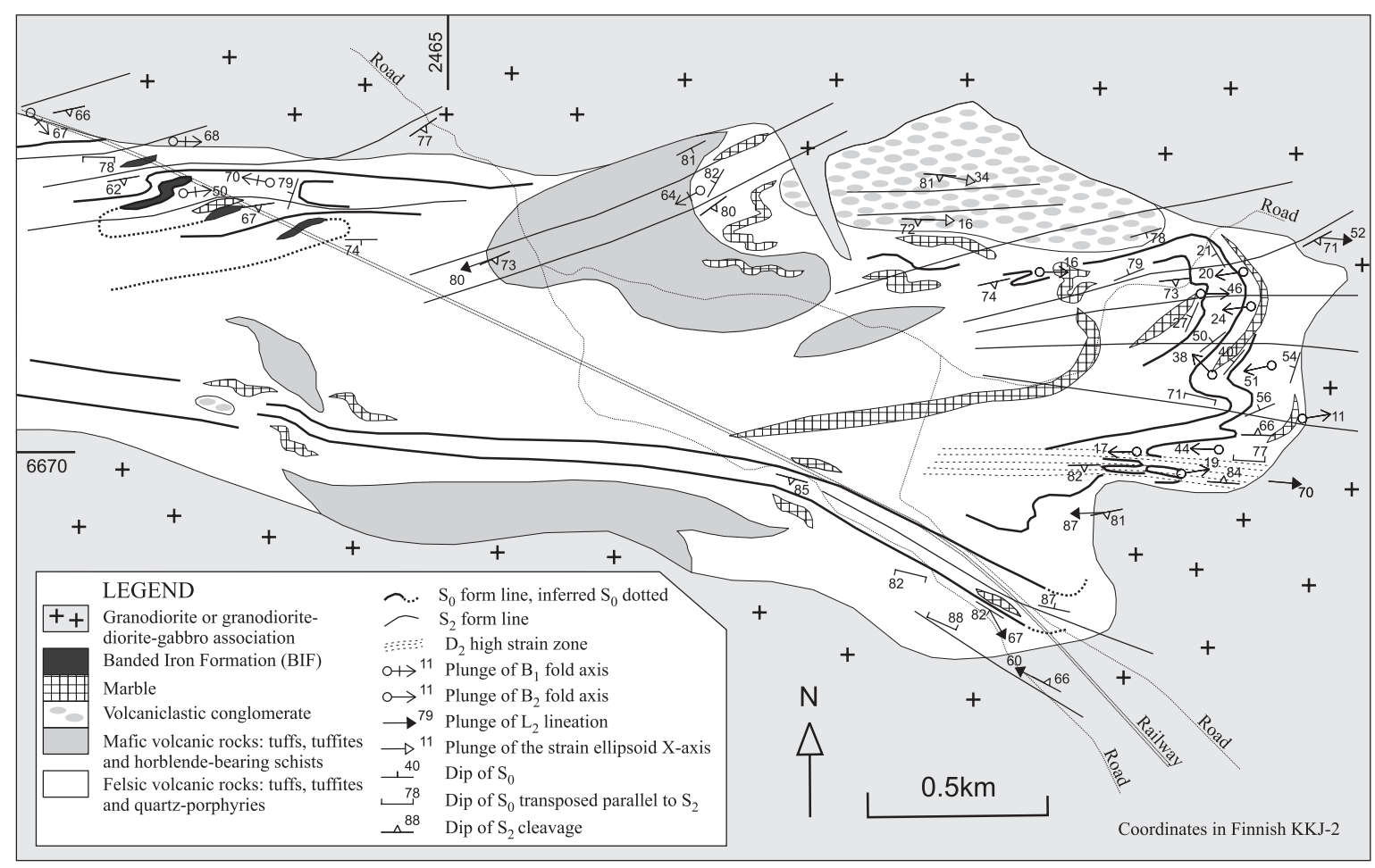

Fig. 2. Geological map of the Kuovila area. Lithology modified after Käpyaho (200I).

composed of purely volcanic material, whereas tuffites are redeposited and contain also sedimentary material. Tuffs and tuffites are bimodal (mafic and felsic), often fine-grained and usually preserve primary bedding $\left(\mathrm{S}_{0}\right)$, including fine lamination, throughout much of the area. Layers are commonly from 2 $\mathrm{cm}$ to a few meters thick. Tuffs and tuffites occasionally have quartz porphyry interlayers with polycrystalline and anhedral quartz from a few $\mathrm{mm}$ to $1 \mathrm{~cm}$ in diameter. Interbeds of calcitic marble and BIF are present within the volcanic rocks. Mafic plagioclase-phyric tuffites and tuffs, as well as schistose layers of even-grained hornblende-bearing tuffs, later here called hornblende schists, are also present. In general, the felsic compositions are more common and the intermediate volcanic rocks are rare.

An unstratified volcaniclastic conglomerate horizon is located in the northern part of the study area. It shows a bimodal composition, with the fragments being felsic and the fine-grained matrix mafic (Tavela, 1950). Fragment size distribution ranges from less than $1 \mathrm{~mm}$ to more than $12 \mathrm{~cm}$, with an average of
$1 \mathrm{~cm}$. Felsic fragments are rounded, variably elongated due to localized strain, and sometimes show weak zoning. Furthermore, microscopic observations reveal angularity of the fragments. Rounded calcite cavities, reaching $10-20 \mathrm{~cm}$ in diameter are also found within the conglomerate.

Sedimentary rocks include marbles and banded iron formations (BIFs). The marbles consist mainly of medium- to coarse-grained calcite. Fine-grained grey dolomite is quite rare. Layering and lamination are the only observed primary structures of the marbles. Rare small sphalerite bands and pods, with occasional galena, are present in marbles near the volcaniclastic conglomerate unit. Skarn formations with diopside, epidote and zoisite are locally present at contact with the marbles and as interlayers within tuffs and tuffites.

Banded iron formations are associated mainly with felsic, fine-grained, laminated tuffs and tuffites and in few places with quartz porphyries. Thicknesses of BIF units generally range from 2 to $10 \mathrm{~m}$. They are thinbedded and laminated, consist principally of separate bands of magnetite, quartz, garnet, and actino- 


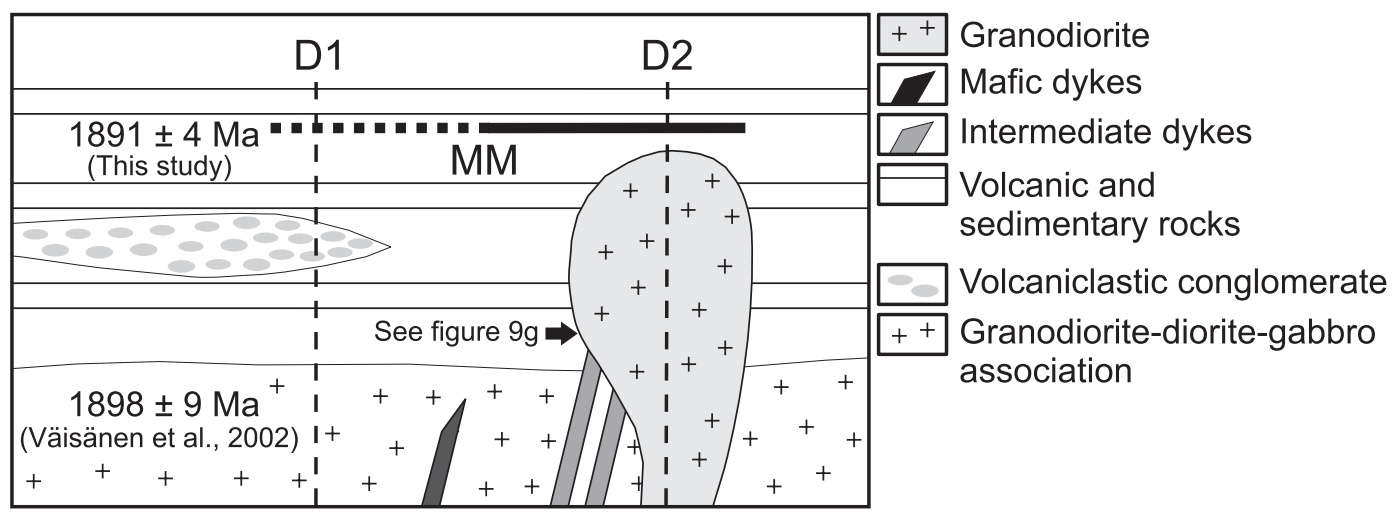

Fig. 3. Crosscutting relationships of the dykes, intrusive and supracrustal rocks relative to deformation and metamorphism (MM) in the Kuovila area.

lite. Calcite and dolomite are only present as accessory minerals.

\subsection{Intrusive rocks and dykes}

Two separate intrusive suites have been identified (Fig. 3). 1) A synvolcanic granodiorite-diorite-gabbro association (cf. Väisänen et al., 2002) has intense tectonic foliation (foliation used for tectonic orientation in the intrusive rocks) and commonly contains mafic magmatic enclaves (MME), whose magmatic origin is established by felsic xenocrysts within the enclaves. The contact relationship between the rocks of this association and the supracrustal rocks of the Kuovila area is, however, not found. 2) A separate, weakly $S_{2}$ -foliated granodiorite intrudes layered volcanic rocks in the $\mathrm{F}_{2}$ fold hinge and along the $\mathrm{F}_{2}$ axial plane, thus being syntectonic with $\mathrm{D}_{2}$. It has a steep quartz aggregate lineation and contains very few MMEs. Microcline granites characteristic for the SSAC are absent.

Mafic plagioclase-phyric dykes and sills, from 10 to $50 \mathrm{~cm}$ wide, often cut the tuffs and tuffites, whereas fine- and even-grained mafic dykes are found to cut the synvolcanic intrusive association. The mafic dykes have a rather uniform orientation and pre-date one major folding event $\left(\mathrm{D}_{2}\right)$. One suite of intermediate dykes comprising an $\mathrm{S}_{2}$ cleavage occurs in the hinge of the $F_{2}$ folds, and is cut by the weakly $S_{2}$-foliated granodiorite. Other intermediate dykes suggest emplacement prior to $D_{1}$, but may, however, not be reliably correlated with deformation events. The intermediate dykes are variably porphyritic in general.

\section{Geochemistry}

\section{I Samples and methods}

Samples for the geochemical analysis were collected from representative rock units, least affected by secondary alteration. Crushing of the samples was made with manganese steel jaw crusher and grinding in carbon steel and tungsten carbide grinding vessels for $\mathrm{X}$ ray fluorescence (XRF) and inductively-coupled plasma mass spectrometry (ICP-MS), respectively. The decomposition of the samples was carried out in two steps: dissolution with hydrofluoric-perchloric acid and making fusion of the undissolved sample with lithium metaborate/sodium perborate. Major elements and $\mathrm{Sr}, \mathrm{Cr}$, $\mathrm{Ni}, \mathrm{Cu}, \mathrm{Zn}, \mathrm{Ga}, \mathrm{Ba}$ and $\mathrm{Pb}$ were determined by XRF on powder pellettes whereas total concentrations the other trace elements (Rb, Th, U, Nb, Zr, Y, Hf, Sc, Ta, V, La, Ce, Pr, Nd, Sm, Eu, Gd, Tb, Dy, Ho, Er, Tm, $\mathrm{Yb}$ and $\mathrm{Lu}$ ) were analysed with ICP-MS at the Geological Survey of Finland. Results and the sample coordinates are presented in Table 1.

\subsection{Whole-rock geochemistry}

\section{Major elements}

In the total alkali vs. silica -diagram all the Kuovila rocks show a bimodal character (Fig. 4a). Exceptions 


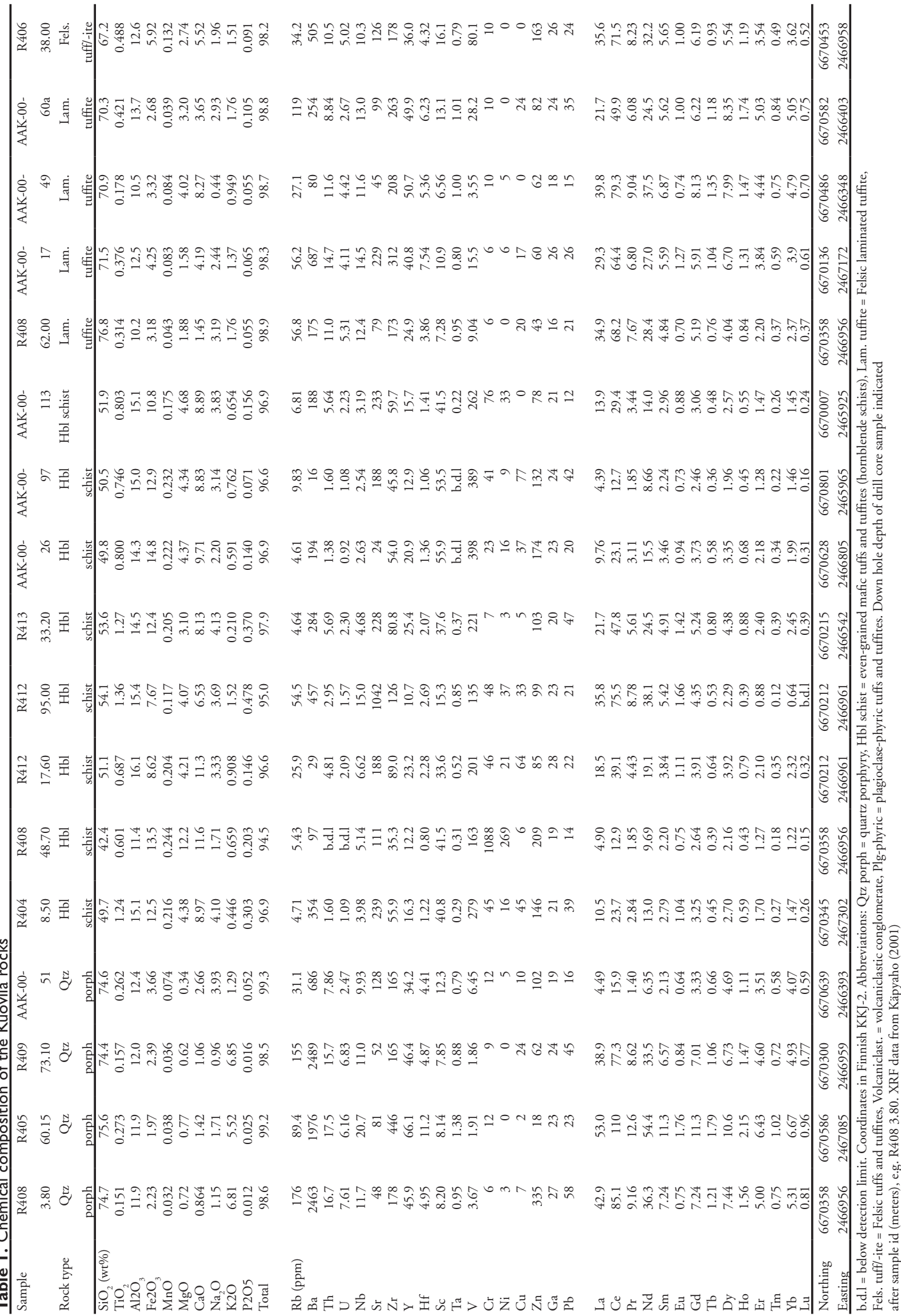




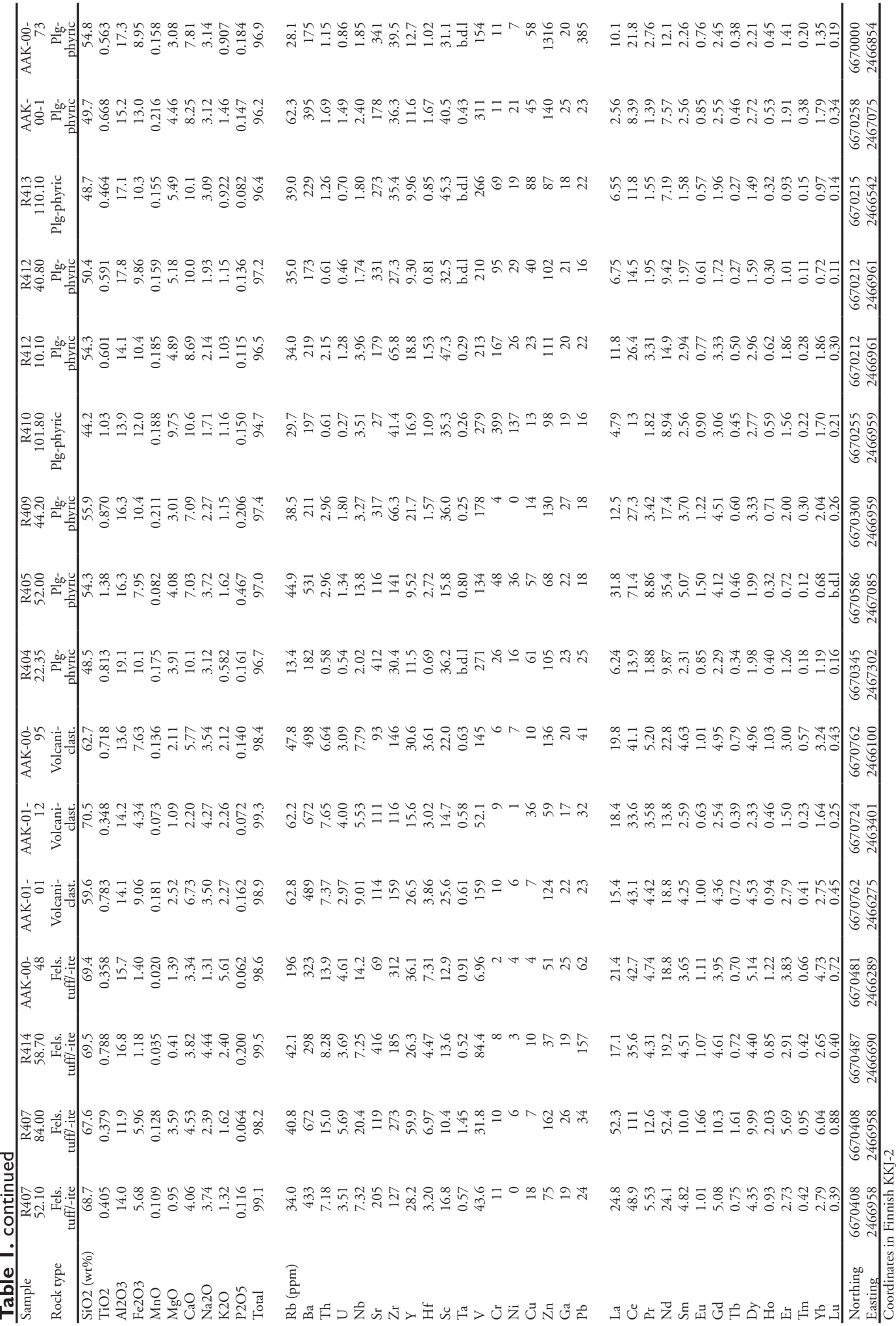



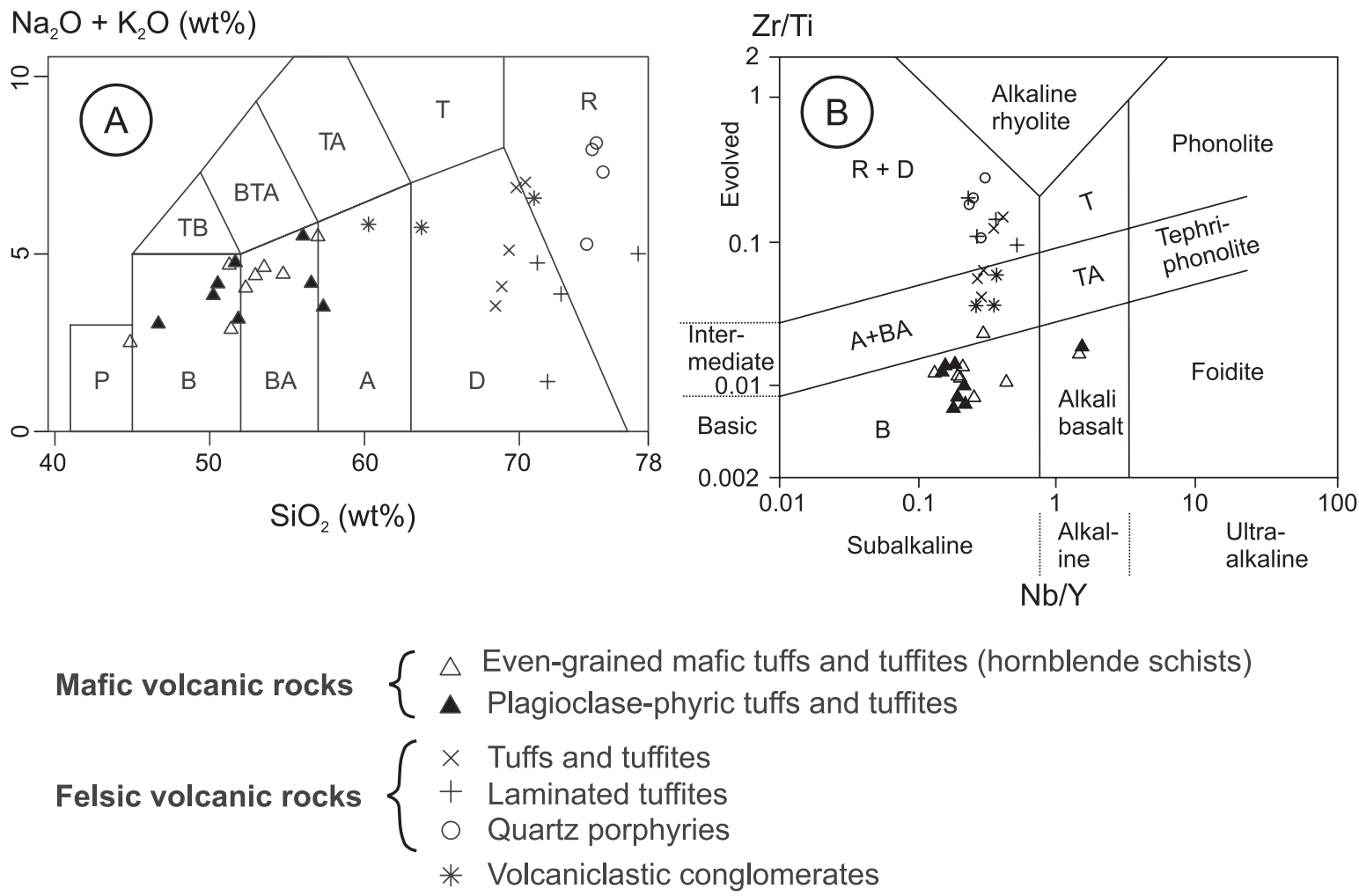

Fig. 4. a) Total alkali vs. $\mathrm{SiO}_{2}$ (TAS) diagram. Fields after Le Bas et al. (1986). $\mathrm{P}=$ Picrobasalt, $\mathrm{B}=$ Basalt, $\mathrm{BA}=$ Basaltic andesite, $\mathrm{A}=$ Andesite, $\mathrm{D}=$ Dacite, $\mathrm{TB}=$ Trachybasalt, $\mathrm{BTA}=$ Basaltic trachyandesite, $\mathrm{TA}=$ Trachyandesite, $\mathrm{T}=$ Trachyte, $\mathrm{R}=$ Rhyolite. b) $\mathrm{Zr} / \mathrm{Ti}$ vs. Nb/Y diagram after Pearce (1996). Fields as in A).

to this are two of the sampled volcaniclastic conglomerates whose bulk compositions are intermediate, reflecting the bimodal composition of the rock, with a mafic matrix and felsic fragments. Plagioclase-phyric tuffs and tuffites and hornblende schists form a homogenous group within basaltic and basaltic andesite fields with one sample in the picrobasalt field. Felsic tuffs and tuffites, laminated tuffites as well as quartz poprhyries plot in the dacite and rhyolite fields. The rhyolitic quartz porphyry samples show a wide range from low-K to mainly shoshonitic compositions (Fig. 5). All the other samples plot within the medium-K field. Immobile element $\mathrm{Zr} / \mathrm{Ti}$ vs. Nb/Y plot after Pearce (1996) (Fig. 4b) also indicates bimodal character of the samples with clusters both in the basalt and in the rhyolite + dacite fields. Similar to the TAS diagram is also the intermediate bulk composition of the volcaniclastic conglomerates. Majority of the samples plot in the subalkaline field (Fig. 4b). For comparison, compositional fields of the major elements of the Orijärvi formation samples are shown in Figure 5. A distinct similarity exists between these two areas. Orijärvi formation samples form slightly tighter groupings compared to the Kuovila samples, while the K-content variation of the quartz porphyry samples of this study most probably indicates alteration.

\section{Trace elements}

Multi-element spider diagrams, chondrite-normalized rare earth element (REE) diagrams and a discrimination diagram by Wood et al. (1979) is shown in order to present the trace element contents of the studied samples. Abbreviations used in the text are large ion lithophile element (LILE), high field 

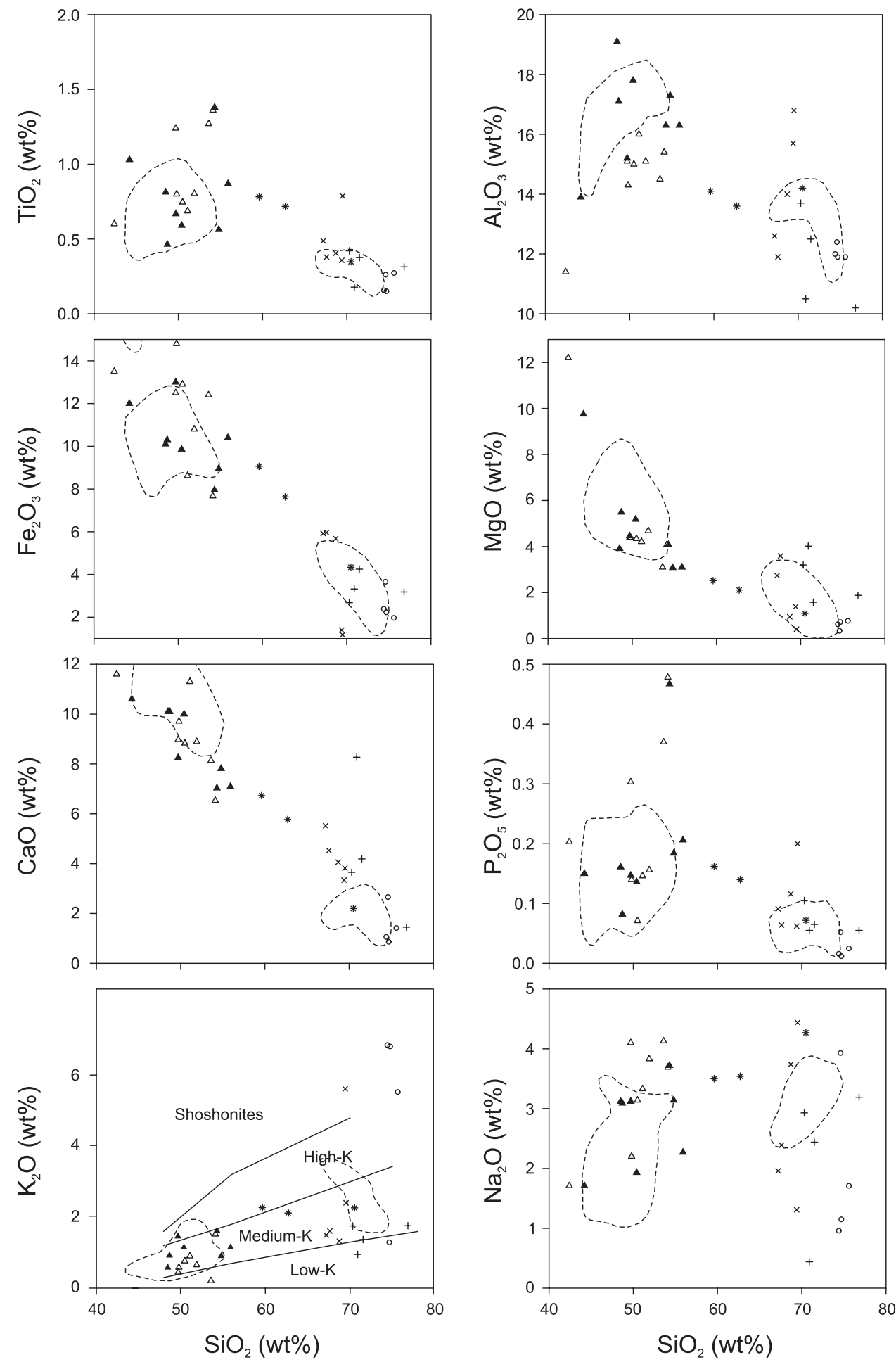

Fig. 5. Major elements vs. $\mathrm{SiO}_{2}$ diagrams. The fields in $\mathrm{SiO}_{2}$ vs. $\mathrm{K}_{2} \mathrm{O}$ diagram after Peccerillo and Taylor (1979). For comparison, geochemical data of the Orijärvi formation samples (after Väisänen \& Mänttäri, 2002) are presented in areas enclosed with dashed line (tot $=2 \mathrm{I}$ samples). One of the Orijärvi formation samples in both $\mathrm{SiO}_{2} \mathrm{vs.} \mathrm{MgO}$ and $\mathrm{SiO}_{2}$ vs. $\mathrm{Al}_{2} \mathrm{O}_{3}$ diagrams plots above the diagram. Symbols as in Fig. 4. 

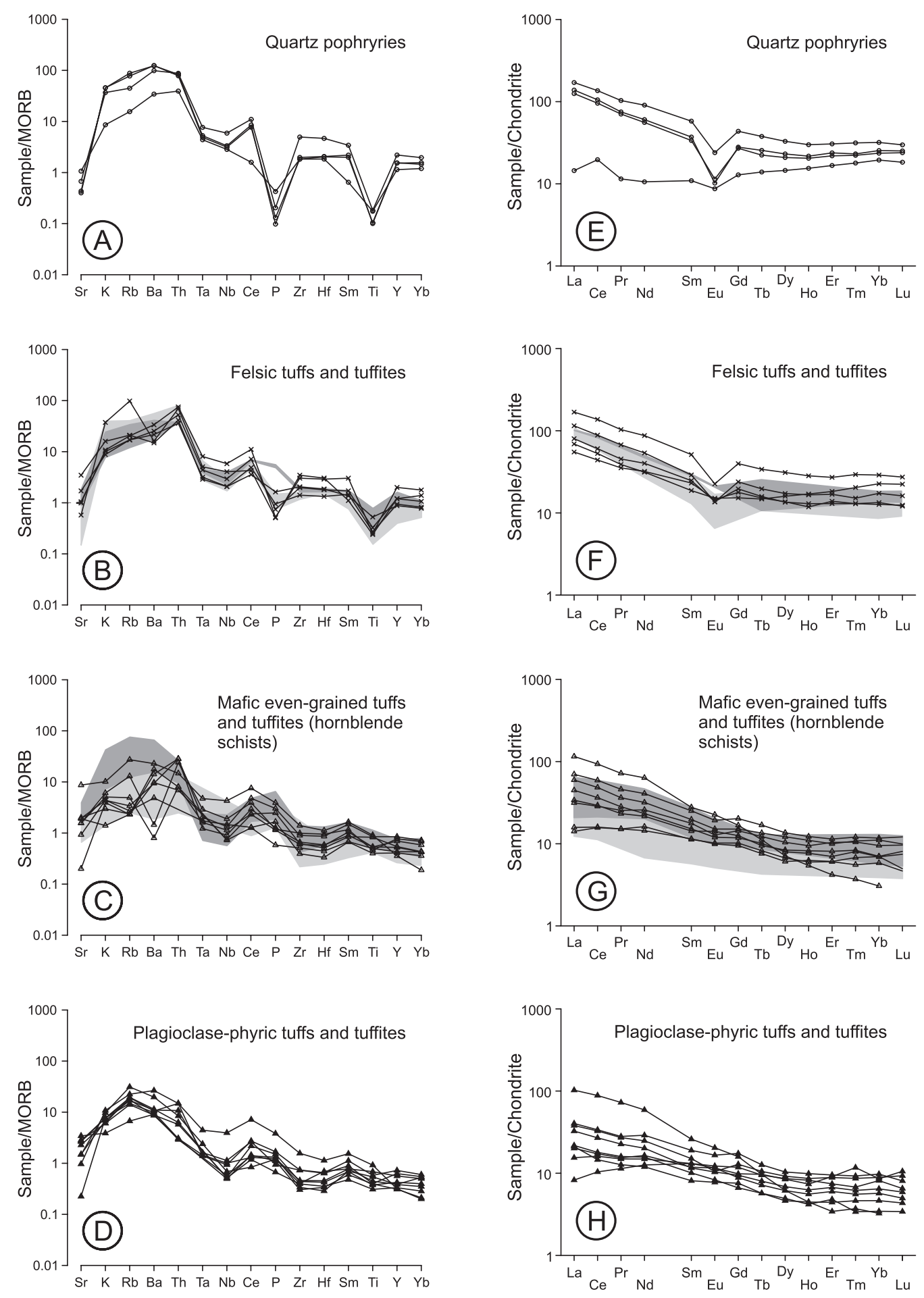

Fig. 6. MORB-normalized multi-element (a-d) and chondrite-normalized REE diagrams (e-h) of the Kuovila area rocks. Dark and light-coloured shading represent compositional fields of the rocks in the Kisko and Orijärvi formations, respectively (Väisänen \& Mänttäri, 2002). Shading in b) and f) stand for felsic rocks and in c) and g) for mafic rocks. Normalizing values for MORB from Pearce (1983) and for chondrite from Boynton (1984). Symbols as in Fig. 4. 
strength element (HFSE), rare earth element (REE), light rare earth element (LREE), heavy rare earth element (HREE), mid-ocean ridge basalt (MORB), and ocean island basalt (OIB). The LILE group contains mobile elements $\mathrm{Cs}, \mathrm{Rb}, \mathrm{K}, \mathrm{Ba}$, Sr and HFSE group contains less mobile elements $\mathrm{Y}, \mathrm{Hf}, \mathrm{Zr}, \mathrm{Ti}, \mathrm{Nb}, \mathrm{Ta}$ and Ce.

All the Kuovila area felsic volcanic rocks show pronounced LREE enrichment and a flat HREE pattern with moderate enrichment in respect to chondritic values (Fig. 6). One of the quartz porphyries has a diverging REE pattern with remarkably lower LREE enrichment compared to the other felsic rocks (Fig. 6e). Felsic volcanic rocks generally show a flat HREE pattern and negative Eu-anomalies, the latter evidently resulting from plagioclase fractionation or plagioclase sustaining in the source residue (Rollinson, 1993). In contrast, the mafic volcanic rocks have a constant slope of the HREE pattern and no Eu-anomalies.

Multi-element spider diagrams of the felsic rocks show slightly higher relative enrichment of LILEs over HFSEs in comparison with the studied mafic rocks. This, together with depletion of $\mathrm{Ti}_{i}$ in the felsic samples is consistent with a fractional crystallization

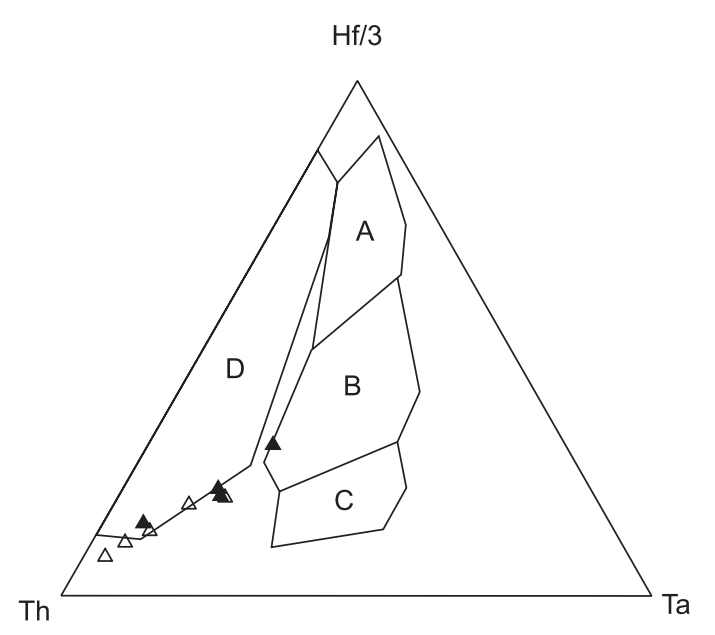

Fig. 7. Tectonic discrimination diagram for basalts after Wood et al. (1979). Key: $A=$ mid-ocean ridge basalt (MORB), $B=$ MORB + within plate basalt (WPB), $C=$ WPB, $D=$ volcanic arc basalt. Symbols as in Fig. 4 . trend from basalt to rhyolite (Pearce, 1996). According to Macdonald et al. (2000; and references therein), enrichment of LILEs relative to LREE and especially relative to HFSEs distinguishes arc magmas from those generated in other tectonic settings, such as MORB and OIB. The distinctive depletion of $\mathrm{Nb}$ and Ta in relation to Th and LREE in all the Kuovila area volcanic rocks indicates volcanic arc settings (Pearce, 1996). Tectonic discrimination diagram for basalts after Wood et al. (1979) also indicates that the Kuovila area mafic volcanic rocks have a volcanic arc affinity (Fig. 7). However, the plotted samples define a trend towards the within plate affinity field and are located at the base of the volcanic arc field, thus indicating geochemical processes typical for a collision zone (Fig. 10b, p. 105 in Pearce, 1996).

In comparison with the Orijärvi formation, REE contents of the Kuovila area mafic volcanic rocks are slightly higher, thus better correlating with the mafic rocks of the Kisko formation (Väisänen \& Mänttäri, 2002). The multi-element diagram patterns of both the Kuovila area felsic and mafic rocks are, nevertheless, nearly identical with the patterns of the felsic and mafic rocks of the Orijärvi formation, respectively. Mafic rocks of the Kisko formation show a more pronounced enrichment of the LILEs compared to the Kuovila area mafic volcanic rocks.

All of the minor and trace element data together with the tectonic discrimination diagram for basalts suggest volcanic arc setting for the Kuovila area volcanism. In addition, major and trace element affinities support correlation of the Kuovila area volcanic rocks with the Orijärvi and Kisko formations, which are interpreted as having formed parts of the same volcanic arc (Väisänen \& Mänttäri, 2002).

\section{Geochronology}

For U-Pb dating a sample from a layered, plagioclase bearing felsic tuff (A1658) was chosen. Zircons from sample Kuovila A1658 are mainly translucent and prismatic; their appearance being typical for magmatic zircons. Four zircon fractions consisting of similar, fine-grained $(<75 \mu \mathrm{m})$ zircons from two density frac- 
Table 2. Multigrain TIMS U-Pb age data from Kuovila tuff, sample Kuovila A 1658. Sample coordinates: 6670498N, 246605 IE (Finnish KKJ-2).

\begin{tabular}{|c|c|c|c|c|c|c|c|c|c|c|c|}
\hline \multirow{2}{*}{$\begin{array}{l}\text { Sample information } \\
\text { Analysed mineral and } \\
\text { fraction }\end{array}$} & \multirow{2}{*}{$\begin{array}{l}\text { Sample } \\
\text { weight/ } \\
\text { mg }\end{array}$} & \multirow{2}{*}{$\begin{array}{l}\mathrm{U} \\
\mathrm{ppm}\end{array}$} & \multirow{2}{*}{$\mathrm{Pb}$} & \multirow{2}{*}{$\begin{array}{l}{ }^{206} \mathrm{~Pb} / \\
{ }^{204} \mathrm{~Pb} \\
\text { meas- } \\
\text { ured }\end{array}$} & \multirow{2}{*}{$\begin{array}{l}{ }^{208} \mathrm{~Pb} / \\
{ }^{206} \mathrm{~Pb} \\
\text { radio- } \\
\text { genic }\end{array}$} & \multicolumn{3}{|c|}{ ISOTOPIC RATIOS ${ }^{1,2)}$} & \multicolumn{3}{|c|}{$\begin{array}{c}\text { APPARENT AGES / Ma } \pm \\
\text { 2sigma }\end{array}$} \\
\hline & & & & & & $\begin{array}{l}{ }^{206} \mathrm{~Pb} / \\
{ }^{238} \mathrm{U}\end{array}$ & $\begin{array}{l}{ }^{207} \mathrm{~Pb} / \\
{ }^{235} \mathrm{U}\end{array}$ & $\begin{array}{l}{ }^{207} \mathrm{~Pb} / \\
{ }^{206} \mathrm{~Pb}\end{array}$ & $\begin{array}{l}{ }^{206} \mathrm{~Pb} / \\
{ }^{238} \mathrm{U}\end{array}$ & $\begin{array}{l}{ }^{207} \mathrm{~Pb} / \\
{ }^{235} \mathrm{U}\end{array}$ & $\begin{array}{l}{ }^{207} \mathrm{~Pb} / \\
{ }^{206} \mathrm{~Pb}\end{array}$ \\
\hline $\begin{array}{l}\text { A) } \mathrm{d}>4.2,-200 \text { mesh, } \\
\text { prismatic, translucent, } \\
\text { abraded } 21 \mathrm{~h}\end{array}$ & 0.49 & 686 & 248 & 2533 & 0.12 & 0.333 & 5.299 & 0.116 & 1851 & 1869 & $1889 \pm 2$ \\
\hline $\begin{array}{l}\text { B) d }>4.2,-200 \text { mesh, } \\
\text { prismatic, translucent }\end{array}$ & 0.59 & 576 & 200 & 1354 & 0.12 & 0.315 & 4.984 & 0.115 & 1764 & 1817 & $1878 \pm 2$ \\
\hline $\begin{array}{l}\text { C) d:4.2-4.0,-200 } \\
\text { mesh, prismatic, trans- } \\
\text { lucent,abraded } 21 \mathrm{~h}\end{array}$ & 0.61 & 913 & 320 & 2772 & 0.13 & 0.323 & 5.114 & 0.115 & 1802 & 1838 & $1880 \pm 2$ \\
\hline $\begin{array}{l}\text { D) d:4.2-4.0,-200mesh, } \\
\text { prismatic,translucent }\end{array}$ & 0.46 & 864 & 281 & 1446 & 0.11 & 0.297 & 4.677 & 0.114 & 1676 & 1763 & $1868 \pm 2$ \\
\hline
\end{tabular}

1) Isotopic ratios corrected for fractionation, blank (50 pg), and age related common lead (Stacey \& Kramers 1975; ${ }^{206 \mathrm{~Pb} /}$ $\left.{ }^{204} \mathrm{~Pb} \pm 0.2,{ }^{207} \mathrm{~Pb} /{ }^{204} \mathrm{~Pb} \pm 0.1,{ }^{208} \mathrm{~Pb} /{ }^{204} \mathrm{~Pb} \pm 0.2\right)$.

2) 2 sigma errors for $\mathrm{Pb} / \mathrm{U}$ and ${ }^{207} \mathrm{~Pb} /{ }^{206} \mathrm{~Pb}$ ratios are $0.65 \%$ and $0.15 \%$, respectively. Error correlations between ${ }^{206} \mathrm{~Pb} /{ }^{238} \mathrm{U}$ and ${ }^{207} \mathrm{~Pb} /{ }^{235} \mathrm{U}$ ratios are 0.97 .

Methods. The datings were performed at GTK, Espoo, Finland. The decomposition of zircons and extraction of $\mathrm{U}$ and $\mathrm{Pb}$ for multigrain TIMS age determinations follows mainly the procedure described by Krogh (1973). ${ }^{235} \mathrm{U}-{ }^{208} \mathrm{~Pb}$-spiked and unspiked isotopic ratios were measured using a VG Sector 54 thermal ionization multicollector mass spectrometer. The measured lead and uranium isotopic ratios were normalized to the accepted ratios of SRM 981 and U500 standards. The Pb/U ratios were calculated using the PbDat-program (Ludwig, 1991) and the fitting of the discordia line as well as calculation of the intercept ages using the Isoplot/Ex 3 program (Ludwig, 2003).

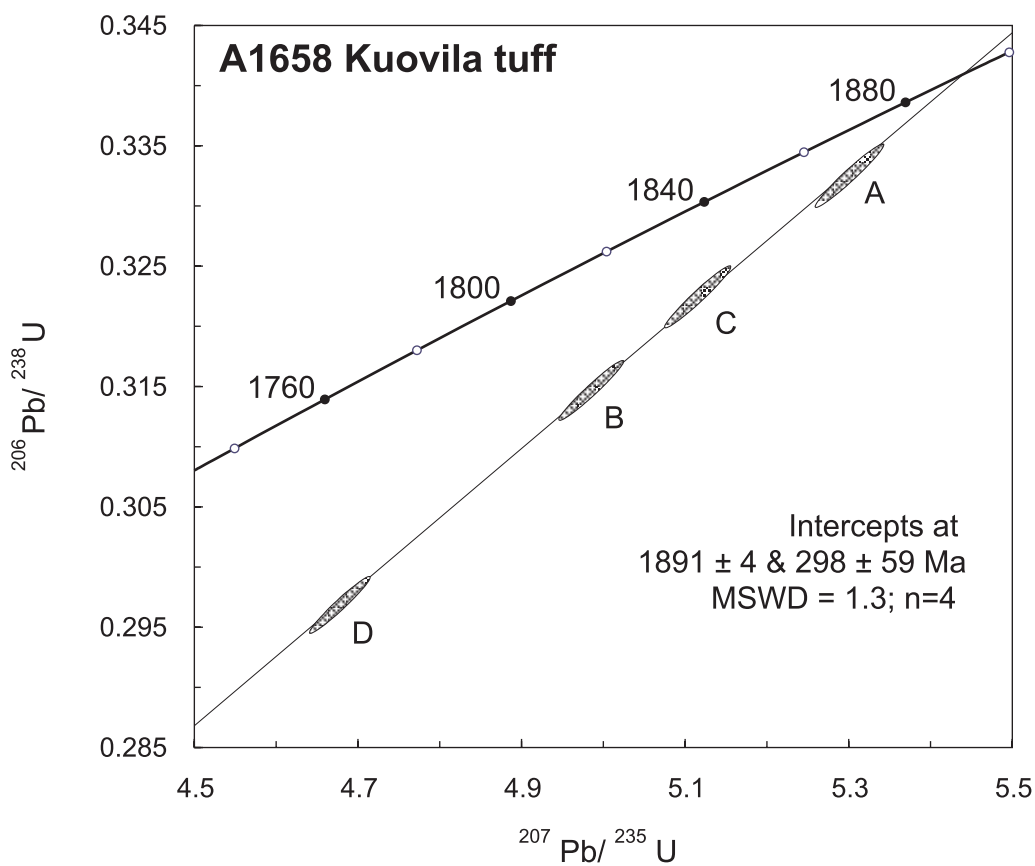

Fig. 8. U-Pb concordia diagram showing the age of the Kuovila tuff. Data point error ellipses are $2 \sigma$. 
tions $\left(\mathrm{d}>4.2 \mathrm{gcm}^{-3}\right.$ and $\left.4.2>\mathrm{d}>4.0 \mathrm{gcm}^{-3}\right)$ were analysed (Table 2). Two of the fractions were air-abraded. All the four analysed fractions plot well on a discordia line which intercepts the concordia curve at $1891.1 \pm 4$ and $298 \pm 59 \mathrm{Ma}(\mathrm{MSWD}=1.3 ; \mathrm{n}=4$ ) (Fig. 8 ). The upper intercept age of $1891 \pm 4 \mathrm{Ma}$ is considered to determine the age of volcanism in the Kuovila area.

\section{Deformation structures}

One regional scale prograde deformational event, $D_{2}$, with associated axial planar cleavage, $S_{2}$, folds $S_{0}$ and a weaker, layer-parallel $S_{1}$ cleavage (Fig. 2). $S_{1}$ has been preserved as inclusion trails within porphyroblasts and as a crenulated early cleavage in the $\mathrm{F}_{2}$ fold hinges. The Kuovila area supracrustal rocks occur within an upright $\mathrm{D}_{2}$ synform with a subhorizontal, curvilinear $B_{2}$ fold axis. The main cleavage $\left(S_{2}\right)$ is subvertical and locally shows fanning across the $\mathrm{F}_{2}$ fold hinges. $\mathrm{D}_{2}$ deformation is locally partitioned into intensely folded high strain zones. Two separate phases of Svecofennian granitoids border the map unit of Kuovila on all sides except on the western side where the supracrustal units continue as part of the E-NE to W-SW trending Uusimaa Belt.

\section{I. Description and relative timing of fabrics, metamorphism and intrusive phases}

$S_{1}$ cleavage in the felsic volcanic rocks, subparallel to layering and defined by alignment of actinolite and biotite grains, is crenulated by $\mathrm{F}_{2}$ folding with associated axial planar $S_{2}$ cleavage (Fig. 9a). $S_{1}$ is rarely visible in outcrop, while the main cleavage $S_{2}$ is generally well developed in mafic layers, but difficult to discern in the felsic quartz and feldspar rich layers (Fig. 9b). Locally, $\mathrm{F}_{2}$ folds with gently plunging axes are associated with axial planar pressure solution cleavages (Fig. 9c). Discrimination between $S_{1}$ and $S_{2}$ cleavages in BIF is difficult due to the parallelism of the $F_{1}$ and $F_{2}$ axial planes on the limb of the large-scale $\mathrm{F}_{2}$ fold, where the folded BIFs are located. Only one cleavage, axial planar to the folds in
BIF (Fig. 9d) is recognized in a chert layer between magnetitic layers. The observed cleavage is either $S_{1}$, which has locally been preserved unaffected by later deformations within rheologically competent units, or $\mathrm{S}_{2}$, in which case a) the pre-existing fabrics were destroyed by annihilation of the mineral grains after $\mathrm{D}_{2}$, or b) no $\mathrm{S}_{1}$ cleavage was developed. The latter alternative is favored by the presence of inclusionfree garnet porphyroblast cores in association with some BIFs and by the mineral composition in the BIF unit, unfavorable for preservation of the earlier fabrics.

Metamorphic mineral growth with respect to the cleavage development indicates two separate stages: garnet grains in a metamorphosed mafic rock grew over $S_{1}$ cleavage, now preserved as an internal $S_{1}$ cleavage within the porphyroblasts, oblique to the external main cleavage of the rock $\left(S_{2}\right)$ (Fig. 9e). Thus, garnet growth was a late/post- $\mathrm{D}_{1}$ and pre- $\mathrm{D}_{2}$ event. Quartz grains in the garnet-bearing rock have been completely recrystallized in equilibrium conditions indicating heating concomitant with or post-dating $\mathrm{D}_{2}$ deformation. It is suggested that there was one progressive metamorphic event, with increasing $\mathrm{P}$ and $\mathrm{T}$ from $\mathrm{D}_{1}$ to peak metamorphic $\mathrm{D}_{2}$. Partial melting conditions were, however, not reached.

The synvolcanic intrusive association is characterized by an intense tectonic foliation and strongly tectonized internal contacts subparallel to the main $\mathrm{S}_{2}$ foliation. The granodiorites of the synvolcanic association contain abundant mafic magmatic enclaves (MMEs) of variable sizes and shapes. Felsic xenocrysts inside the MMEs indicate comagmatic origin for the rocks of the association (Fig 9f). The syn- $\mathrm{D}_{2}$ granodiorite occurs in the hinge zone of the large $\mathrm{F}_{2}$ fold in the eastern part of the study area. A porphyritic intermediate dyke, both truncating $S_{0}$ in a felsic volcanic and being included within the syn- $\mathrm{D}_{2}$ granodiorite, provides clear evidence of the crosscutting relationships (Figure 9g). The both intrusives comprise an $S_{2}$ but no evidence of $S_{1}$. The granodiorite intrudes the layered volcanic rock both along $S_{0}$ and $\mathrm{F}_{2}$ axial plane, thus indicating syn- $\mathrm{D}_{2}$ origin. The intermediate dykes occur in the $\mathrm{F}_{2}$ fold hinges, most 

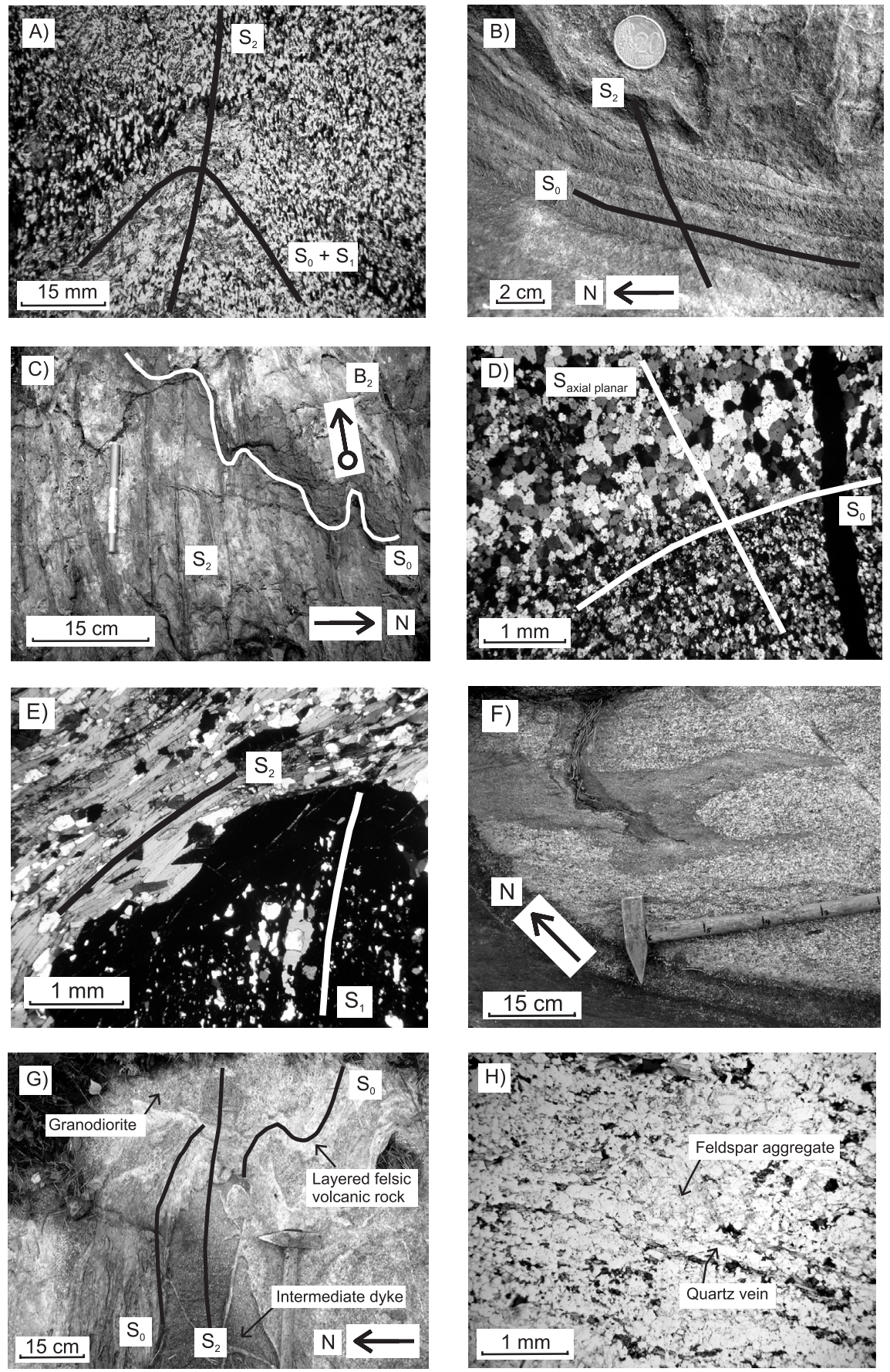

Fig. 9. Photomicrographs and outcrop photos. a) Photomicrograph of $D_{2}$ crenulated $S_{1}$ in the hinge of a $F_{2}$ fold with shallow $B_{2}$ axis. Outcrop is located in the hinge zone of the larger $F_{2}$ fold. Plane-polarized light (ppl). b) Well-developed $S_{2}$ cleavage in mafic layers in the hinge zone of the larger $F_{2}$ synform. c) Axial planar zonal $S_{2}$ pressure solution cleavage cross-cutting shallow $\mathrm{S}_{0}$. d) Photomicrograph of a quartz-rich layer between magnetite-rich layers in a BIF exhibiting an axial planar cleavage. See text for origin of the cleavage. Cross-polarized light (cpl). e) Photomicrograph of pre- $D_{2}$ garnets with an internal $S_{1}$ foliation inclined to the external $S_{2}$ cleavage (cpl). f) Flow shapes and felsic xenocrysts within mafic magmatic enclaves in granodiorite indicating comagmatic origin for the rocks. g) A syn- $D_{2}$ granodiorite truncating both the $\mathrm{S}_{2}$-foliated intermediate dyke and the layered felsic volcanic rock. Note the weak $\mathrm{S}_{2}$ foliation in the granodiorite. Locality 46-PMSK-04 (6669976N, 2467072E, coordinates in Finnish KKJ2). h) Photomicrograph of elongate quartz veinlets and sheared K-feldspar porphyroclasts in granodiorite (ppl). 
A) Fold axes

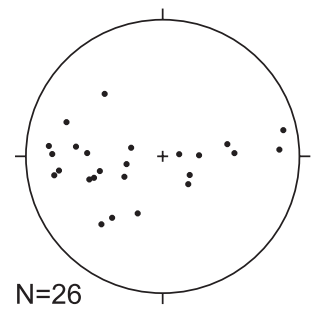

All Kuovila area fold axes.
B) Bedding planes

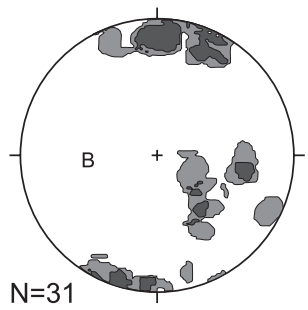

Poles to bedding planes. Densities $4 \%$ and $8 \%$, max. $16,1 \%$. Statistical B-axis $(265 / 36)$ indicated.

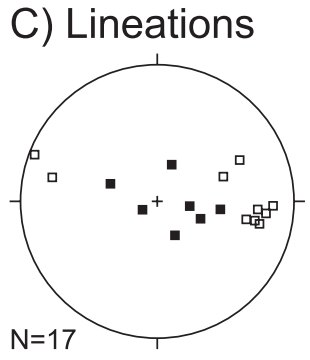

All Kuovila area lineations: Filled squares $=\mathrm{L}_{2}$ stretching Densities $1 \%, 2 \%, 4 \%, 8 \%$, lineations, open squares =strain ellipsoid $\mathrm{x}$-axes.
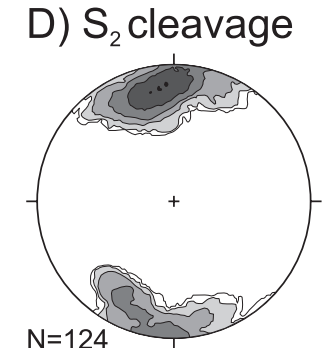

Poles to $\mathrm{S}_{2}$ cleavage planes. $16 \%, 32 \%$, max. $33,87 \%$.

Fig. 10. Stereographic projections of the main structural elements of the study area (lower hemisphere, equal area projections).

probably indicating emplacement between $\mathrm{D}_{1}$ and $\mathrm{D}_{2}$, or early/syn- $\mathrm{D}_{2}$. Another observation supporting the presence of two distinctly separate intrusive phases is where a granodiorite with less intense $S_{2}$ foliation intrudes strongly foliated older diorite comprising MMEs and inclusions of isoclinally folded layered felsic volcanic rocks.

The two granitoid phases exhibit rather similar microstructures: 1) grain aggregates of almost pure K-feldspar, sheared in a brittle/rigid style to produce sigma-shaped porphyroclasts, as revealed by boudinage of the clasts and associated, dynamically recrystallized quartz-rich tails (Fig. 9h). 2) Veinlets of quartz consisting of stretched elongate quartz grains, indicating medium-grade metamorphic conditions with temperatures between 400 and $700^{\circ} \mathrm{C}$ (Passchier \& Trouw, 1996). The deformation microstructures in intrusive rocks are consistent with heating during or subsequent to the main deformation, recorded by the static equilibrium structures with triple junctions of 120-degree angles within the K-feldspar aggregates.

\subsection{Geometry of the Kuovila area deformation structures}

Geometry of the deformation structures in the study area is characterized by E-W trends on the large-scale $\mathrm{F}_{2}$ fold limbs, and by closure of the fold in the east.
Two discontinuous marble horizons act as lithological markers (Fig. 2). Fold axes in the area are subparallel in the map view, but show frequent changes in plunge, with both easterly or westerly plunges occurring within small areas (Fig. 2). The steep to subvertical fold axes plunge W-WSW whereas the gentler fold axes trend slightly more E-W (Fig. 10). The folds with steep axes generally occur as symmetric open folds with an $S_{0}$ enveloping surface at high angles to the strike of the $\mathrm{D}_{2}$ axial planes on the outcrop scale (Fig. 11a). They are interpreted as $\mathrm{D}_{2}$-transposed $\mathrm{F}_{1}$ folds within the $\mathrm{D}_{2}$ low strain zone. Folds in the $\mathrm{D}_{2}$ high strain zone have gentle, curvilinear axes. Bedding planes are tightly to isoclinally folded and boudinage occurs on the fold limbs (Fig. 11b). Figure 12 illustrates typical geometry of folding with variable fold axial plunges in a $\mathrm{D}_{2}$ high strain zone. In conclusion, regional geometry of the supracrustal rocks at Kuovila indicates $\mathrm{D}_{1}$ folded bedding planes prior to $\mathrm{D}_{2}$ folding. The absence of well-developed $S_{1}$ cleavages indicates either moderate intensity or localization of $\mathrm{D}_{1}$ folding or that $\mathrm{D}_{1}$ occurred in a low- $\mathrm{T}$ regime, with little mineral growth. Small-scale $\mathrm{D}_{1}$ thrust planes are found locally. Bedding planes in the $\mathrm{F}_{2}$ fold hinge generally have shallow to moderate westerly dips with some steeper values present, too (Fig. 10). Statistically defined $\mathrm{B}$-axis thus stands for an average of the curvilinear $\mathrm{B}_{2}$ axis. 

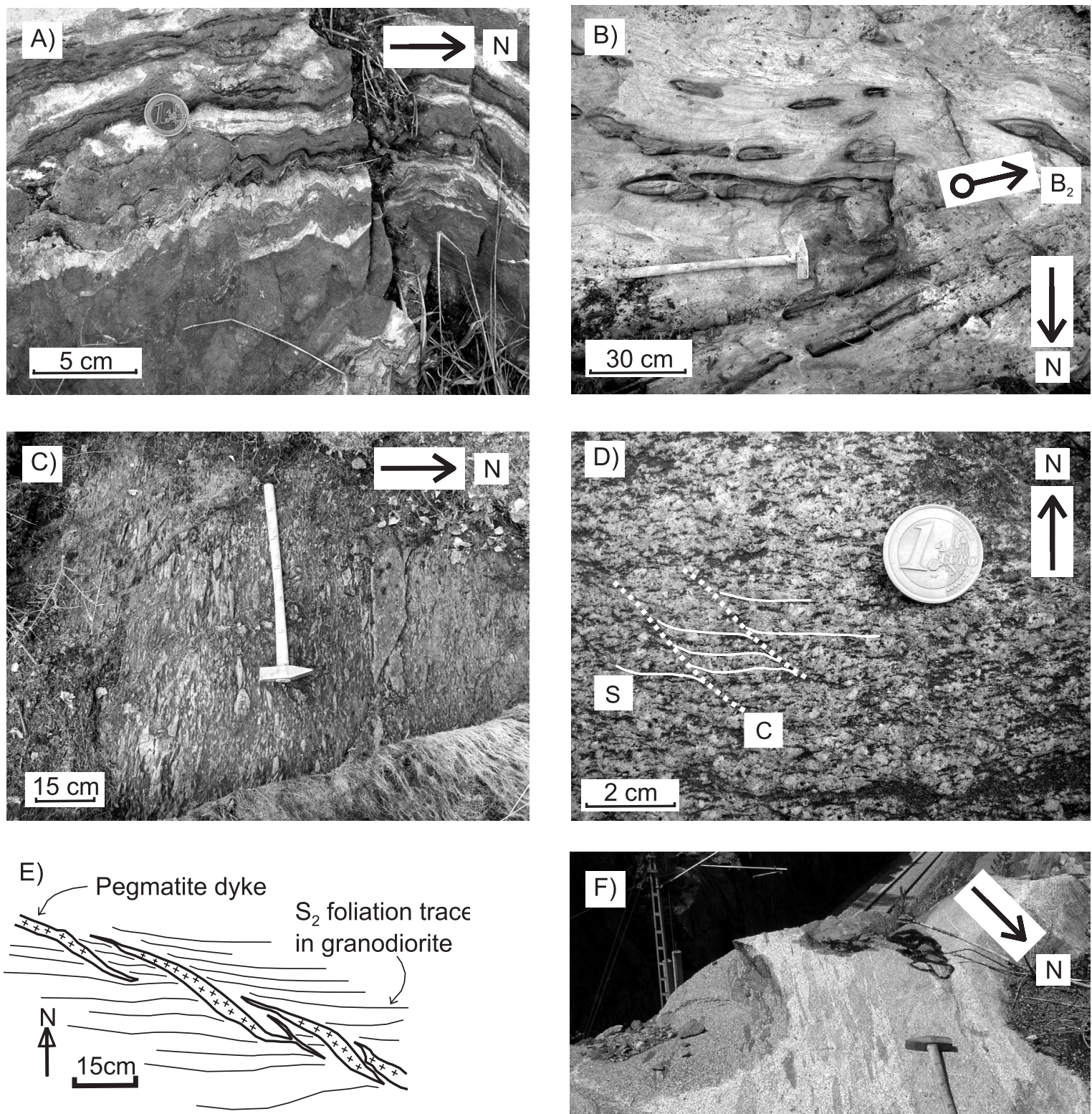

Fig. I I. Outcrop photos. a) An open, m-symmetric $F_{\text {I }}$ fold with steep axis. b) $F_{2}$ fold with a shallow fold axis plunging $W$ in $D_{2}$ high strain zone. Bedding planes are boudinaged on the fold limbs. Mineral composition of the rock is unfavourable for the development of a strong $\mathrm{S}_{2}$ cleavage. c) Volcaniclastic conglomerate formation with strained fragments, $X Z$ plane of the strain ellipsoid in a zone of a higher cumulative strain within the conglomerate. d) Dextral S/C fabric in granodiorite. e) Pegmatite dykes intruding a granodiorite of the synvolcanic intrusive association (line drawing). f) Intensely strained enclaves of variable composition in the synvolcanic granodiorite.

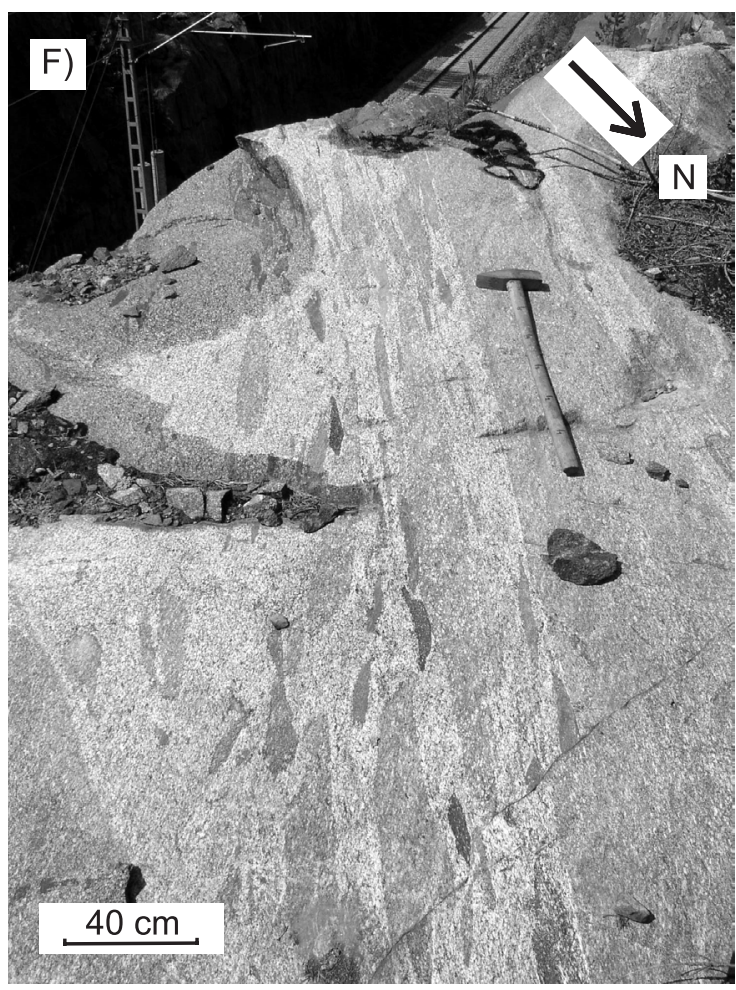




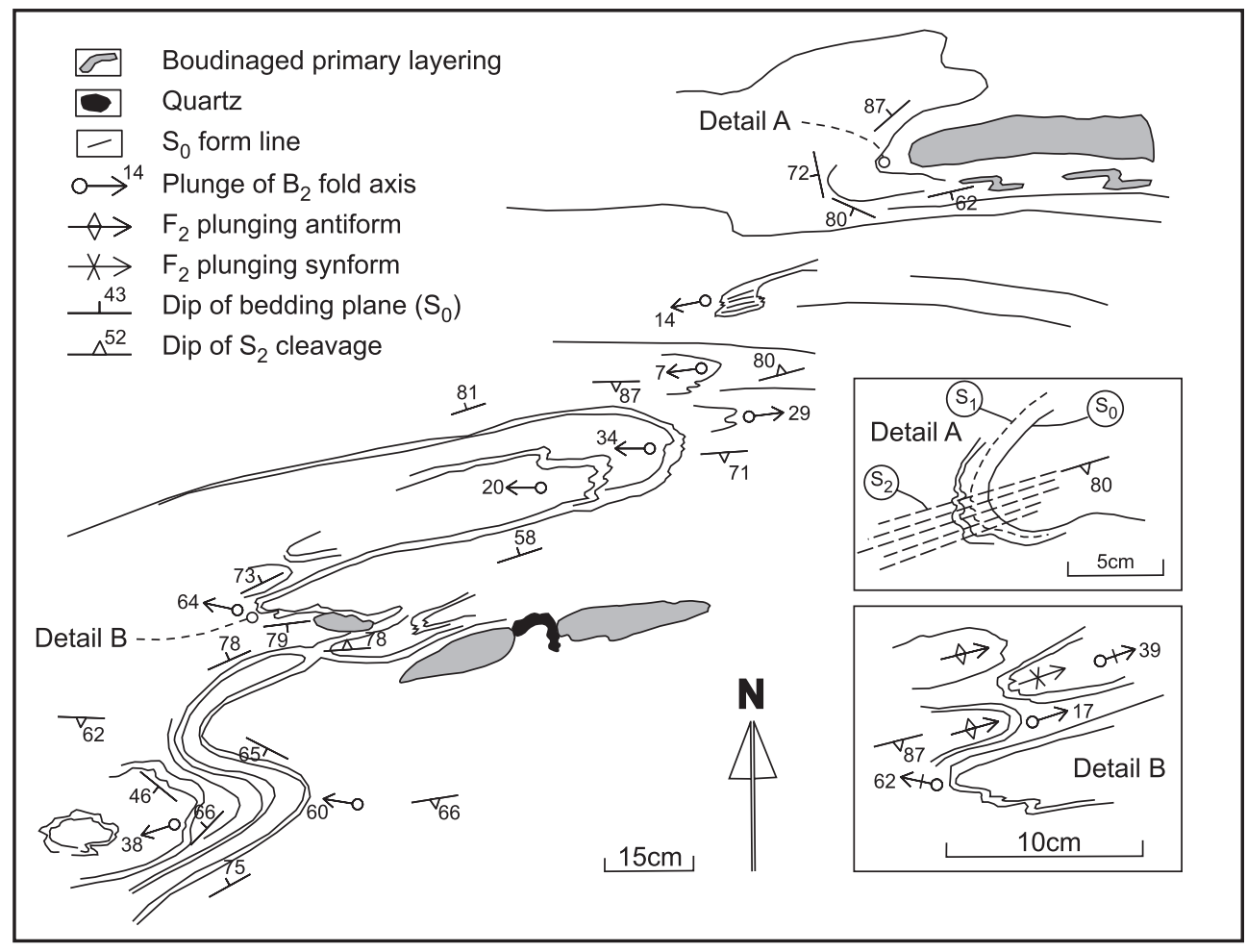

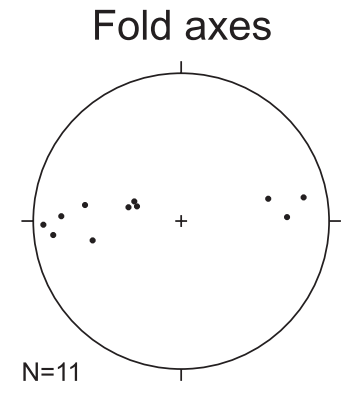

All fold axes.
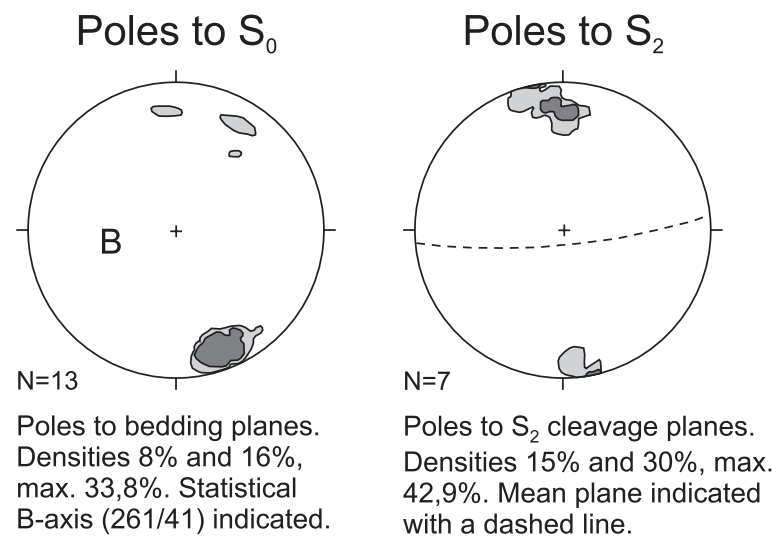

Fig. 12. Detailed map of folding in $\mathrm{D}_{2}$ high strain zone with stereoplots of the associated structural elements. Note the variation in plunges of the fold axes. Locality 39-PMSK-04 (66700 I7N, 2466920E, coordinates in Finnish KKJ-2).

\section{Discussion}

\section{I. Structural evolution, strain partitioning and deformation kinematics}

Three lines of evidence suggest recumbent $F_{1}$ folds overprinted by upright $\mathrm{F}_{2}$ folds:

1) The map pattern, where the folded marble horizons most probably are fragments of a single poly- deformed layer. Strong attenuation and boudinage of the layer on fold limbs and thickening and buckling in the fold hinges probably took place both during $\mathrm{D}_{1}$ and $\mathrm{D}_{2}$. Absence of outcrop scale fold interference structures suggests large $F_{1}$ fold amplitudes compared to the $\mathrm{F}_{2}$ folds, and a rather uniform, flat-lying $F_{1}$ fold limbs prior to $D_{2}$. 2) Stereographic analysis of the fold axes (Fig. 10a): The presently steep fold 
axes were originally subhorizontal $\mathrm{B}_{1}$ fold axes trending NNE to SSW, now rotated into steep orientation about the gently plunging regional $\mathrm{B}_{2}$ fold axes. 3) Local, small-scale $D_{1}$ thrusts, suggesting thrusting towards ESE may have accompanied the $\mathrm{F}_{1}$ folding. The principal stretch axes $(\mathrm{X})$ in the zones of the highest cumulative strain, defined by strained fragments in the conglomerates, are subparallel to the gentle regional fold axes (Fig. 10). The $\mathrm{X}$-axis orientation, however, probably indicates tectonic transport direction during $\mathrm{D}_{1}$, which likely was perpendicular to the axes of the thrust-related, recumbent $\mathrm{F}_{1}$ folds. Fragments within volcaniclastic conglomerate unit indicate moderate flattening strains with average aspect ratios of approximately $(\mathrm{x}: \mathrm{y}: \mathrm{z})=2.5$ : 2 : 1. It is likely that the XY plane represents transposed $S_{1} / S_{2}$ cleavage plane, subparallel to $S_{2}$ orientation in the nearby volcanic and sedimentary units, with some intensifying of the fabric during $\mathrm{D}_{2}$. Locally, constrictional strains with prolate clast shapes occur in specific locations (Fig. 11c).

Tavela (1950) also described early layer-parallel deformation structures from the Kuovila area. In relation to Svecofennian orogenic evolution elsewhere, early thrusting is consistent with the previous studies (van Staal \& Williams, 1983; Bleeker \& Westra, 1987; Ehlers et al., 1993). However, tectonic transport directions are variable as Ehlers et al. (1993) describes early folds overturned to the north and west, van Staal \& Williams (1983) thrusting towards north, whereas the present study suggests thrusting towards SSE. Therefore, regional kinematics of the earliest tectonic stages in orogenic scale remains poorly constrained.

Some $\mathrm{D}_{1}$ structures and fabrics are possibly preserved as a result of spatial $\mathrm{D}_{2}$ strain variation with partitioning into axial planar high strain zones on the limbs of the large-scale $\mathrm{F}_{2}$ fold and low strain domains in between. The low strain domains occur in the $\mathrm{F}_{1}$ hinge zones within the rheologically competent units, such as BIFs, which have been acting as nearly rigid blocks that have mainly been "passively" rotated into their present position during $\mathrm{D}_{2}$ with only minor "internal" strain. Thus, the main reason for the spatial $\mathrm{D}_{2}$ strain variation would be the spatial distribution and geometry of the competent rheological units at the onset of $\mathrm{D}_{2}$ stage.

$\mathrm{D}_{2}$ of the Kuovila area probably correlates with the first tectonometamorphic event with associated migmatization and forming of the first penetrative fabric at ca. $1.88 \mathrm{Ga}$ in the southern SSAC (Hopgood et al., 1983), but has taken place at higher crustal levels not involving migmatization. This is also favored by the absence of K-feldspar rich granites associated with migmatizing veins in the Kuovila area, characteristic for the 1.84-1.81 Ga event (Nironen, 2003). Deformations during the 1.84-1.81 Ga event also fold the main fabric of the rocks, whereas the Kuovila area supracrustals have the main fabric in the $\mathrm{F}_{2}$ axial planes, similar to the Orijärvi triangle (Plogsma \& Westra, 1990). Thus, combined with the very similar lithological and geochemical characteristics, $\mathrm{D}_{2}$ deformation structures within the Kuovila area most probably correlate with $\mathrm{D}_{1}$ of Ploegsma \& Westra (1990). The possibility of the Kuovila area $\mathrm{D}_{2}$ being related to the 1.84-1.81 Ga event, may, however, not be reliably ruled out without an absolute age determination for $\mathrm{D}_{2}$ in the Kuovila area.

$\mathrm{D}_{2}$ folds are resulting from horizontal, approximately N-S contraction. The curvilinear patterns of the $B_{2}$ fold axes probably result from vertical stretching perpendicular to the $\mathrm{B}_{2}$ axes during $\mathrm{D}_{2}$, associated with steep mineral aggregate lineations in the syn- $\mathrm{D}_{2}$ granodiorite (Fig. 10). One possibility for the variation of the fold axial plunges would be refolding of $\mathrm{F}_{2}$ folds. No evidence for such folding is however present in the Kuovila area. Location of the area bounded between NE-SW and NW-SE trending regional high strain zones has likely inhibited post- $\mathrm{D}_{2}$ deformation in the Kuovila area, as in the Orijärvi low-strain triangle (Ploegsma \& Westra, 1990). Therefore, it may be concluded that vertical movements, considered at least partly responsible for the doming of the Svecofennian Mustio dome (Härme, 1953; Bleeker \& Westra, 1987; Veenhof \& Stel, 1991) took place already during $\mathrm{D}_{2}$ of the Kuovila area, now suggested to correlate with $\mathrm{D}_{1}$ of the earlier studies (Bleeker \& Westra, 1987; Ploegsma \& Westra, 1990), thus predating the doming at Mustio. 


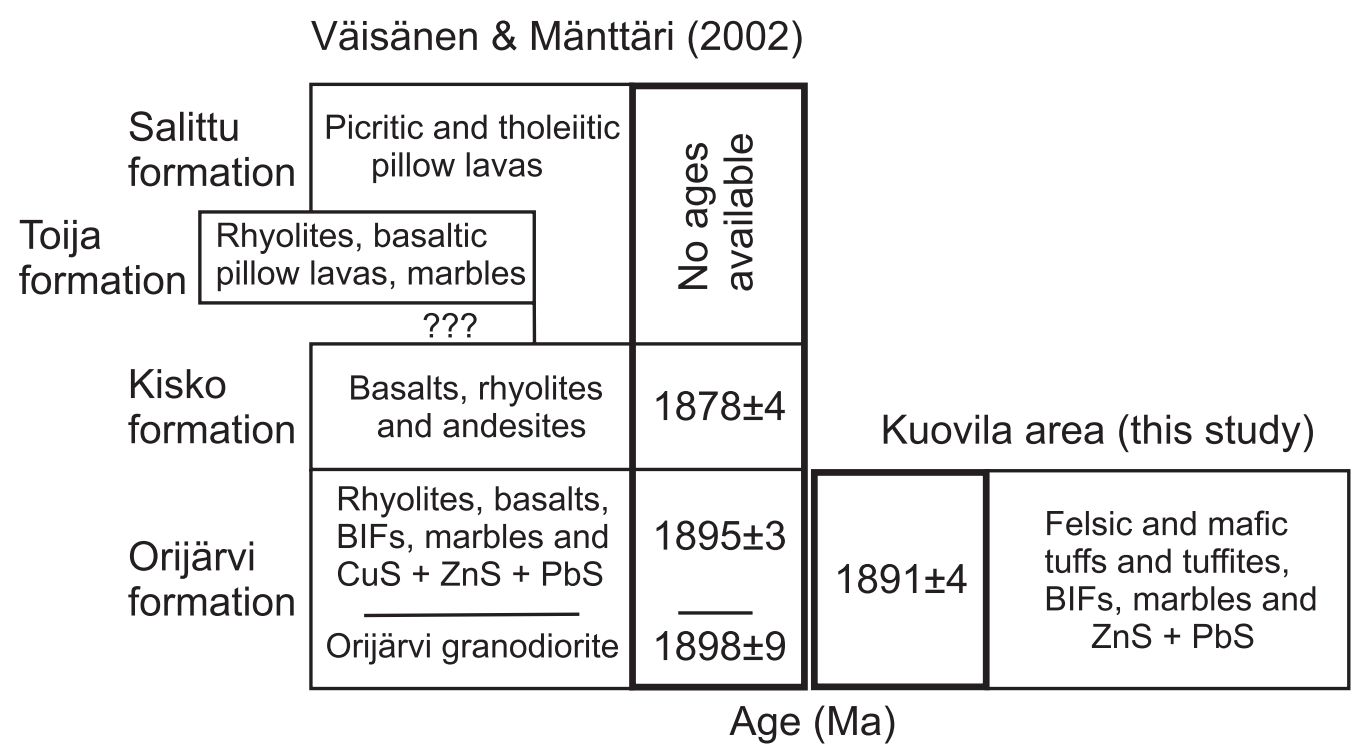

Fig. 13. Correlation of the Kuovila area rocks with the stratigraphy of the Orijärvi area (Väisänen \& Mänttäri, 2002).

Origin of the dextral S/C fabrics in the synvolcanic granodiorite (Fig. 11d) either results from shearing or oblique overprinting of $S_{2}$ over $S_{1}$, as do the dextral en-echelon arrays in pegmatite veins intruding the granodiorite (Fig. 11e). Weak, gently plunging lineations related to shearing in the granodiorite would indicate dextral, mainly strike-slip movements along EW trending shear zones, thus consistent with the regional interpretation of transpressive deformation deforming the $-1.84-1.83$ Ga old granites within the SSAC (Ehlers et al., 1993). Localization of cumulative strain in the synvolcanic intrusive association, revealed by variably flattened MMEs in different parts of the intrusive (Fig. 11f), is also suggested to relate to the strike-slip shearing, possibly during the vaning stages of the orogeny at $-1.8 \mathrm{Ga}$.

\subsection{Regional geotectonic correlation}

Geochemical data show a distinct similarity between the Kuovila area and the Orijärvi and Kisko formations described by Väisänen \& Mänttäri (2002). The Kisko formation, however differs lithologically from the Kuovila and the Orijärvi areas, which both comprise BIFs, marbles (Eskola, 1914; Mäkelä, 1989; Keinänen, 1980) and sulphide mineralizations shar- ing very similar $\mathrm{ZnS}$-PbS-CuS distributions (Mäkelä, 1989; Käpyaho, 2001). The amount of sulphide mineralization and the degree of hydrothermal alteration are higher at Orijärvi.

Age of the volcanism is $1895 \pm 3 \mathrm{Ma}$ in the basal parts of the Orijärvi formation, $1878 \pm \mathrm{Ma}$ at higher stratigraphical level in the Kisko formation (Väisänen \& Mänttäri, 2002) and 1891ะ4 Ma for the Kuovila felsic tuff. Within error limits, these ages in the Kuovila and Orijärvi are therefore contemporaneous. These features suggest that these areas can probably be correlated (Fig. 13). However, the wider main element distribution and the higher REE contents of the former in some respects resemble also the Kisko and Salittu formations overlying the Orijärvi formation (Väisänen \& Mänttäri, 2002). The volcanic rocks of the Kuovila area and the Orijärvi formation represent the earliest identified volcanic stage in the southern Svecofennian Uusimaa Belt, also being concurrent with the Bergslagen area of south-central Sweden (Lundström et al., 1998).

The possible correlation of the $\mathrm{D}_{2}$ in the Kuovila area with the early deformation structures pre-dating the metamorphic peak and the associated S-type granites at - 1.84-1.82 Ga elsewhere in the Uusimaa Belt, possibly implies two separate structural succes- 
sions. These both would be characterized by very similar deformational events including early recumbent, thrust-related folds overprinted by upright EW trending folds caused by N-S crustal contraction (e.g. Schreurs \& Westra, 1986; Ehlers et al., 1993). It is also possible that the structural succession within the Kuovila area represents deformation structures related to the - 1.84-1.82 Ga event, but at higher crustal levels, not including partial melting. This is, however, not favoured by the granodioritic composition of the syn- $\mathrm{D}_{2}$ intrusive in the Kuovila area. Anyhow, dating of the structural events both in the migmatitic and non-migmatitic domains of the SSAC will be needed to discriminate between the structural successions related to the older and the younger tectonothermal events.

\section{Conclusions}

1. Volcanism in the Kuovila area is geochemically similar to the modern-day volcanic arc environment and similar to the stratigraphically lowermost volcanic rocks in the Orijärvi area. A felsic tuff in the Kuovila area, dated at $1891 \pm 4 \mathrm{Ma}$ by U-Pb isotopes analyzed on zircons, is contemporaneous with volcanic rocks in the Orijärvi formation. Thus, the Kuovila area volcanic rocks and the Orijärvi formation represent the same stage and approximately the same stratigraphical horizon in the evolution of Southern Svecofennian Arc Complex.

2. Approximately horizontal N-S contraction during the peak metamorphic $\mathrm{D}_{2}$ resulted the upright $\mathrm{F}_{2}$ folds now defining the Kuovila synform. $\mathrm{D}_{2}$ is associated with axial planar $S_{2}$ cleavages and curvilinear $B_{2}$ fold axes. $\mathrm{D}_{2}$ strain is partitioned into low strain domains and narrow high strain zones. Metamorphic conditions did not reach partial melting during $\mathrm{D}_{2}$. $\mathrm{D}_{1}$ structures probably were low metamorphic and localized, thrust-related recumbent folds with large amplitudes.

3. Emplacement of a granodioritic intrusive phase took place syntectonic with $\mathrm{D}_{2}$ deformation.

\section{Acknowledgements}

We wish to thank staff at the geochemistry laboratory at the Geological Survey of Finland (GTK) for the geochemical analyses, Marita Niemelä at the isotope laboratory at GTK and mineral separation staff for heavy liquid mineral separation. Andrej Wennström and Jouko Pääkkönen prepared the thin sections. Jarmo Kohonen, Peter Sorjonen-Ward and one anonymous referee is thanked for critical reviews of the manuscript, and Petri Peltonen for the editorial handling of the manuscript. Rod Holcombe is thanked for a critical review of an earlier version of the manuscript. Discussions with Mikko Nironen and Timo Kilpeläinen were instructive. Pentti Hölttä helped with the metamorphic matters during the work. Nick Oliver pointed out several important details in the field and in thin sections. Jukka Reinikainen and Olli Sarapää are acknowledged for cooperation in the early stages of the project. Pekka Karimerto and Jukka Kaunismäki are thanked for assistance in sampling. Colleagues at GTK are acknowledged for inspiring discussions. The National Graduate School of Geology and GTK funded this work.

\section{References}

Allen, R.L., Lundström, I., Ripa, M., Simeonov, A. \& Christofferson, H., 1996. Facies analysis of a 1. 9 Ga, continental margin, back-arc. Felsic caldera province with diverse $\mathrm{Zn}-\mathrm{Pb}-\mathrm{Ag}$ - $(\mathrm{Cu}-\mathrm{Au})$ sulphide and $\mathrm{Fe}$ oxide deposits, Bergslagen Region, Sweden. Economic Geology 91, 979-1008.

Bleeker, W. \& Westra, L., 1987. The evolution of the Mustio gneiss dome, Svecofennides of SW Finland. Precambrian Research 36, 227-240.

Gorbatshev, R. \& Bogdanova, S., 1993. Frontiers in the Baltic Shield. Precambrian Research 64, 3-21.

Boynton, W.V., 1984. Geochemistry of the rare earth elements: meteorite studies. In: Henderson, P. (ed.) Rare earth element geochemistry. Elsevier, p. 63-114.

Colley, H. \& Westra L., 1987. The volcano-tectonic setting and mineralization of the early Proterozoic Kemiö-Orijärvi-Lohja belt, SW Finland. In: Pharaoh, T.C., Beckinsale, R.D., Rickard, D. (eds.) Geochemistry and mineralizations of Proterozoic volcanic suites. Geological Society Special Publications 33, 95-107.

Ehlers, C., Lindroos, A. \& Selonen, O., 1993. The late Svecofennian granite-migmatite zone of southern Finlanda belt of transpressive deformation and granite emplacement. Precambrian Research 64, 295-309.

Ekdahl, E., 1993. Early Proterozoic Karelian and Svecofennian formations and the evolution of the Raahe-Ladoga ore zone, based on the Pielavesi area, central Finland. Geological Survey of Finland, Bulletin 373, 137 p.

Eskola, P., 1914. On the petrology of the Orijärvi region 
in southwestern Finland. Bulletin de la Commission Géologique de Finlande 40, 277 p.

Eskola, P., 1915. On the relations between the chemical and mineralogical composition in the metamorphic rocks of the Orijärvi region. Bulletin de la Commission Géologique de Finlande 44, 145 p.

Eskola, P.E., Hackman, V., Laitakari, A. \& Wilkman, W.W., 1919. Suomen kalkkikivi. Geologisen komission geoteknisiä julkaisuja N:o 21, 265 p. (in Finnish).

Gaál, G., 1990. Tectonic styles of early Proterozoic ore deposition in the Fennoscandian Shield. Precambrian Research 46, 83-114.

Hietanen, A., 1975. Generation of potassium-poor magmas in the northern Sierra Nevada and Svecofennian of Finland. Geological Society of America Bulletin 58, 1019-1085.

Hopgood, A.M., Bowes, D.R., Kouvo, O. \& Halliday, A.N., 1983. U-Pb and Rb-Sr isotopic study of polyphase deformed migmatites in the Svecocarelides, southern Finland. In: Atherton, M.P. \& Gribble, C.D. (eds.) Migmatites, melting and metamorphism. Shiva, Cheshire. 8092.

Huhma, H., 1986. Sm-Nd, U-Pb and Pb-Pb isotopic evidence for the origin of the Early Proterozoic Svecokarelian crust in Finland. Geological Survey of Finland, Bulletin 337, $48 \mathrm{p}$.

Härme, M., 1953. Structure and stratigraphy of the Mustio area, southern Finland. Bulletin de la Commission Géologique de Finlande 166, 29-48.

Jurvanen, T., Eklund, O. \& Väisänen, M., 2005. Generation of A-type granitic melts during the late-Svecofennian metamorphism in southern Finland. GFF 127, 139147.

Keinänen, V., 1980. Orijärven alueen rautakerrostumista. M.Sc. Thesis, University of Turku, Finland (in Finnish), $85 \mathrm{p}$.

Koistinen, T., 1992. Tammisaari. Explanation to the Geological map of Finland 1:100 000, pre-Quarternary rocks, sheet 2014, 10 p (in Finnish).

Korsman, K., Korja, T., Pajunen, M., Virransalo, P. \& GGT/SVEKA Working group, 1999. The GGT/SVEKA Transect: Structure and Evolution of the Continental Crust in the Paleoproterozoic Svecofennian Orogen in Finland. International Geology Review 41, 287-333.

Krogh, T.E., 1973. A low-contamination method for hydrothermal decomposition of $\mathrm{U}$ and $\mathrm{Pb}$ for isotopic age determinations. Geochimica et Cosmochimica Acta 37, 485-494.

Kurhila, M., Vaasjoki, M., Mänttäri, I., Rämö, T. \& Nironen, M., 2004. Conventional and ion-probe U-Pb results on the lateorogenic microcline granites in southern Finland. In: Mansfeld, J. (ed.) The $26^{\text {th }}$ Nordic Geological Winter Meeting, Uppsala, Sweden. GFF 126, 27.

Käpyaho, A., 2001. Pohjan Kuovilan karbonaattikivien esiintymisympäristön petrologia ja geokemia.. M.Sc. Thesis, University of Helsinki, Finland (in Finnish), 74 p.
Latvalahti, U., 1979. Cu-Zn-Pb Ores in the Aijala-Orijarvi area, Southwest Finland. Economic Geology 79, 1035-1059.

Le Bas, M.J., Le Maitre, R.W. Streckeisen, R. \& Zanettin, B., 1986. A Chemical Classification of Volcanic Rocks Based on the Total Alkali-Silica (TAS) Diagram. Journal of Petrology 27, 745-750.

Levin, T., Engström, J., Lindroos, A., Baltybaev, S. \& Levchenkov, O., 2005. Late-Svecofennian transpressive deformation in SW Finland - evidence from late-stage D3 structures. GFF 127, 129-137.

Ludvig, K.R., 1991. PbDat 1.21 for MS-dos: A computer program for IBM-PC Compatibles for processing raw $\mathrm{Pb}-\mathrm{U}-\mathrm{Th}$ isotope data. Version 1.07. U.S. Geological Survey Open-File Report, 88-542, 35 p.

Ludwig, K.R., 2003. Isoplot/Ex 3. A geochronological toolkit for Microsoft Excel. Berkeley Geochronology Center. Special publication No. 4.

Lundström, I., \& Papunen, H., (eds.) 1986. Mineral deposits of soutwestern Finland and the Bergslagen province, Sweden. Sveriges Geologiska Undersökning, Ser. Ca 61.44 p.

Lundström, I., Allen, R.L., Persson, P-O. \& Ripa, M., 1998. Stratigraphies and depositional ages of Svecofennian, Palaeoproterozoic metavolcanic rocks in E. Svealand and Bergslagen, south central Sweden. GFF 120, 315-320.

Macdonald, R., Hawkesworth, C.J. \& Heath, E., 2000. The Lesser Antilles volcanic chain: a study in arc magmatism. Earth-Science Reviews 49, 1-79.

Mouri, H., Väisänen, M., Huhma, H. \& Korsman, K., 2005. Sm-Nd garnet and U-Pb monazite dating of highgrade metamorphism and crustal melting in the West Uusimaa area, southern Finland. GFF 127, 123-128.

Mäkelä, U., 1983. On the geology of the Aijala-Orijärvi area, southwest Finland. In: Laajoki, K. \& Paakkola, J. (eds.) Exogenic processes and related metallogeny in the Svecokarelian geosynclinal complex. Guide to field trips for the IGCP Projects 91 and 160 in eastern, central and southern Finland, August 17-26, 1983. Geological Survey of Finland, Guide 11, 140-160.

Mäkelä, U., 1989. Geological and geochemical environments of Precambrian sulphide deposits in southwestern Finland. Annales Academi Scientiarum Fennicae III 151,102 p.

Nironen, M., 1997. The Svecofennian orogen: a tectonic model. Precambrian Research 86, 21-44.

Nironen, M., 2003. Renewed classification of Proterozoic orogenic granitoid rocks in Finland. In: Rämö, O.T., Kosunen, P.J., Lauri, L.S. \& Karhu, J.A. (eds.) Granitic Systems - State of Art and Future Avenues. An International Symposium in Honor of Professor Ilmari Haapala, January 12-14, 2003, Abstract Volume. Helsinki University Press, 120 p.

Passchier, C.W. \& Trouw, R.A.J., 1996. Microtectonics. Springer Verlag, Berlin. 289 p.

Pearce, J.A., 1983. Role of subcontinental lithosphere in 
magma genesis at active continental margins. In: Hawkesworth, C.J. \& Norry, M.J. (eds.) Continental Basalts and Mantle Xenoliths. Nantwich: Shiva, 230-249.

Pearce, J.A., 1996. A User`s Guide to Basalt Discrimination Diagrams. In: Wyman, D.A. (ed.) Trace Element Geochemistry of Volcanic Rocks: Applications for Massive Sulphide Exploration. Geological Association of Canada, Short Course Notes, vol. 12, 79-113.

Pearce, J.A., Harris, N.B.W. \& Tindle, A.G., 1984. Trace element discrimination diagrams for the tectonic interpretation of granitic rocks. Contributions to Mineralogy and Petrology 25, 956-983.

Peccerillo, R. \& Taylor, S.R., 1976. Geochemistry of Eocene calc-alkaline volcanic rocks from the Kastamonu area, northern Turkey. Contributions to Mineralogy and Petrology 58, 63-81

Ploegsma, M. \& Westra, L., 1990. The Early Proterozoic Orijärvi triangle (southwest Finland): a key area on the tectonic evolution of the Svecofennides. Precambrian Research 47, 51-69.

Reinikainen, J., 2001. Petrogenesis of paleoproterozoic marbles in the Svecofennian domain, Finland. Geological Survey of Finland, Report of investigation 154, 84 p.

Rollinson, H.R., 1993. Using Geochemical Data: Evaluation, Presentation, Interpretation. Longman, Essex. $352 \mathrm{p}$.

Schreurs, J. \& Westra, L. 1986. The thermotectonic evolution of a Proterozoic, low pressure, granulite dome, West Uusimaa, SW Finland. Contributions to Mineralogy and Petrology 93, 236-250.

Sipilä, P., 1981. Lounais-Suomen rautamalmeista. M.Sc. Thesis, University of Turku, Finland (in Finnish), 106 p.

Simonen, A., 1953. Stratigraphy and sedimentation of the Svecofennidic, early Archean supracrustal rocks in SouthWestern Finland. Bulletin de la Commission Géologique de Finlande 160, 37-64.

Stacey, J.S. \& Kramers, J.D. 1975. Approximation of terrestrial lead isotope evolution by a two-stage model. Earth and Planetary Science Letters 26, 207-221.

Suominen, V., 1991. The chronostratigraphy of southwestern Finland with special reference to Postjotnian and Subjotnian diabases. Geological Survey of Finland, Bulletin $356,100 \mathrm{p}$.

Tavela, M., 1950. Havaintoja Kuovilan alueelta KiskonKemiön leptiittivyöhykkeellä. M.Sc. Thesis, University of Helsinki, Finland (in Finnish), 57 p.

Tuominen, H., 1957. The structure of an Archean area: Orijärvi, Finland. Bulletin de la Commission Géologique de Finlande 177, 32 p.

van Staal, C.R. \& Williams, P.F., 1983. Evolution of a Svecofennian-mantled gneiss dome in SW Finland, with evidence for thrusting. Precambrian Research 21, 101128.

Verhoef, P.N.W. \& Dietvorst, E.J.L, 1980. Structural analysis of differentiated schists and gneisses in the Taalinte- hdas area, Kemiö Island, southwest Finland. Bulletin of the Geological Society of Finland 52, 147-164.

Väisänen, M., and Mänttäri, I., 2002. 1.90-1.88 Ga arc and back-arc Basin in the Orijärvi area, SW Finland. Bulletin of the Geological Society of Finland 74, 185-214.

Väisänen, M., Mänttäri, I. \& Hölttä, P., 2002. Svecofennian magmatic and metamorphic evolution in sothwestern Finland as revealed by U-Pb zircon SIMS geochronology. Precambrian Research 116, 111-127.

Wood, D.A., Joron, J-L. \& Treuil, M., 1979. A re-appraisal of the use of trace elements to classify and discriminate between magma series erupted in different tectonic settings. Earth and Planetary Science Letters 45, 326-336. 